\title{
Familial Distal Renal Tubular Acidosis Is Associated with Mutations in the Red Cell Anion Exchanger (Band 3, AE1) Gene
}

\author{
Lesley J. Bruce, ${ }^{\star}$ Diane L. Cope, ${ }^{\star}$ Graham K. Jones, ${ }^{\star}$ Ann E. Schofield, ${ }^{\star}$ Mariwyn Burley, ${ }^{\ddagger}$ Susan Povey, ${ }^{\ddagger}$ Robert J. Unwin, ${ }^{\S}$ \\ Oliver Wrong, ${ }^{\S}$ and Michael J.A. Tanner* \\ *Department of Biochemistry, School of Medical Sciences, University of Bristol; ${ }^{\ddagger}$ MRC Human Biochemical Genetics Unit, University \\ College London; and ${ }^{\S}$ Centre for Nephrology, University College London Medical School, United Kingdom
}

\begin{abstract}
All affected patients in four families with autosomal dominant familial renal tubular acidosis (dRTA) were heterozygous for mutations in their red cell $\mathrm{HCO}_{3}{ }^{-} / \mathrm{Cl}^{-}$exchanger, band 3 ( $A E 1, S L C 4 A 1)$ genes, and these mutations were not found in any of the nine normal family members studied. The mutation $\operatorname{Arg}_{589} \rightarrow$ His was present in two families, while $\operatorname{Arg}_{589} \rightarrow$ Cys and $\mathrm{Ser}_{613} \rightarrow$ Phe changes were found in the other families. Linkage studies confirmed the co-segregation of the disease with a genetic marker close to $A E 1$. The affected individuals with the $\operatorname{Arg}_{589}$ mutations had reduced red cell sulfate transport and altered glycosylation of the red cell band $3 \mathrm{~N}$-glycan chain. The red cells of individuals with the $\operatorname{Ser}_{613} \rightarrow$ Phe mutation had markedly increased red cell sulfate transport but almost normal red cell iodide transport. The erythroid and kidney isoforms of the mutant band 3 proteins were expressed in Xenopus oocytes and all showed significant chloride transport activity. We conclude that dominantly inherited dRTA is associated with mutations in band 3; but both the disease and its autosomal dominant inheritance are not related simply to the anion transport activity of the mutant proteins. (J. Clin. Invest. 1997. 100:1693-1707.) Key words: erythrocyte • kidney • acidosis • membrane $\bullet$ nephrocalcinosis
\end{abstract}

\section{Introduction}

In distal renal tubular acidosis (dRTA $)^{1}$ the tubular secretion of hydrogen-ion in the distal nepron is impaired, leading to the development of metabolic acidosis, frequently accompanied

A preliminary account of part of this work has been presented in a report of a meeting of Physicians and Scientists at University College London Medical School.

Address correspondence to Michael J.A. Tanner, Department of Biochemistry, School of Medical Sciences, University of Bristol, University Walk, Bristol BS8 1TD, United Kingdom. Phone: $(+44)-117-$ 9288271; FAX: (+44)-117-9288274; E-mail: m.tanner@bristol.ac.uk. D.L. Cope's present address is Department of Biochemistry, University of Glasgow, United Kingdom. A.E. Schofield's present address is Department of Biochemistry, University of Otago, Dunedin, New Zealand.

Received for publication 25 April 1996 and accepted in revised form 14 August 1997.

J. Clin. Invest.

(C) The American Society for Clinical Investigation, Inc. 0021-9738/97/10/1693/15 \$2.00

Volume 100, Number 7, October 1997, 1693-1707

http://www.jci.org by hypokalemia, nephrocalcinosis, and metabolic bone disease (1). The condition can be familial, when it is usually inherited as an autosomal dominant, though there is a rarer autosomal recessive form associated with nerve deafness.

The molecular basis of familial dRTA is not known. Suggestions (1-3) include defects in either the $\mathrm{H}^{+}$-ATPase or the $\mathrm{H}^{+} / \mathrm{K}^{+}$-ATPase on the apical membrane of the $\mathrm{H}^{+}$-secreting $\alpha$-intercalated cells in the collecting duct, or an increased permeability of this membrane causing excess back-diffusion of secreted $\mathrm{H}^{+}$, resulting in a failure to establish or maintain a cell-to-lumen hydrogen ion gradient. A further possibility, which has received little attention, is a defect in the $\mathrm{HCO}_{3}{ }^{-} / \mathrm{Cl}^{-}$ anion exchanger (AE1, band 3 ) on the basolateral membrane of this cell type (3).

The members of the anion exchanger $(A E)$ gene family (4, $5)$ are widely distributed in tissues, where they are involved in the regulation of intracellular $\mathrm{pH}$, cell volume and the transcellular transport of acid and base across epithelial cells. There are at least three members of the $A E$ gene family, and the very abundant form present in red cells (AE1 or band 3) has been studied in some detail (6). Red cell band 3 is a protein of $\sim 95$ $\mathrm{kD}$ with two distinct functions: the $40-\mathrm{kD} \mathrm{NH} \mathrm{N}_{2}$-terminal domain extends into the red cell cytoplasm and acts as a membrane anchorage site for the red cell skeleton, while the $\mathrm{COOH}$-terminal 55-kD domain carries out anion transport.

The $A E 1$ gene (also known as SLC4A1 and EPB3) has a relatively restricted expression in tissues. As well as being present in erythroid cells, an AE1 gene product is also found in the basolateral membrane of the $\alpha$-intercalated cells of kidney collecting ducts which are involved in acid secretion (7-9). Studies of the major AE1 transcripts, carried out first in mouse and rat kidney $(10,11)$, and more recently in human kidney (12) suggest that the kidney form of AE1 is truncated at the $\mathrm{NH}_{2}$ terminus because it lacks exons $1-3$ of the erythroid form $(10,11)$. A promoter which gives rise to these kidney transcripts is present in erythroid intron 3 of the human $A E 1$ gene $(12,13)$. Studies on human kidney have shown that while the protein in the basolateral membrane of $\alpha$-intercalated cells is reactive towards monoclonal antibodies to the membrane transport domain of $\operatorname{AE} 1(7,14)$, several antibodies to the cy-

1. Abbreviations used in this paper: AE1, (AE2, AE3), anion exchanger 1 (2, 3); DIDS, 4,4'-di-isothiocyanato-stilbene-2,2' -disulfonate; DNDS, 4,4' -dinitro-2,2' -stilbene disulfonate; dRTA, distal renal tubular acidosis; GPA, glycophorin A; nt, nucleotide; PNGase F, peptide N-glycosidase F; R589C, $\mathrm{Arg}_{589} \rightarrow$ Cys mutation; R589H, $\mathrm{Arg}_{589} \rightarrow$ His mutation; S613F, Ser $_{613} \rightarrow$ Phe mutation; SAO, Southeast Asian Ovalocytosis; SITS, 4-acetamido-4' -isothio-cyano-2,2'-stilbene disulfonate; SSCP, single-strand conformation polymorphism. 
toplasmic domain of AE1 are unreactive (7), also consistent with renal AE1 being truncated at the $\mathrm{NH}_{2}$ terminus.

We have examined the possibility that patients with autosomal dominant familial dRTA might have altered $\mathrm{HCO}_{3}^{-} /$ $\mathrm{Cl}^{-}$exchange, resulting from changes in AE1, which lead to reduced $\mathrm{H}^{+}$secretion and urinary acidification. This might be revealed by analysis of the properties of AE1 in red cells, which are much more readily available and amenable to biochemical analysis than renal tissue. In this report we describe different mutations in the $A E 1$ gene which are associated with the presence of dominant familial dRTA and also result in altered red cell anion exchanger structure and function.

\section{Methods}

The 18 patients with dRTA reported here were members of four families from Southeast England, all with at least two generations affected (see Fig. 1). Table I shows the data from which this diagnosis was made. Families A and B have already been reported in part (15, 16). Studies were performed on the 16 affected and 9 unaffected survivors of these four families. Most patients presented clinically with renal stones, and the majority had nephrocalcinosis. B:1:4 had rickets when initially seen aged 10, and developed osteomalacia aged 31 after she stopped taking alkali therapy, but no other patient had bone disease. Eight patients were not acidotic when first seen, and were diagnosed as "incomplete" dRTA $(17,18)$ because they were unable to excrete a urine more acid than $\mathrm{pH} 5.3$ after oral acute ammonium chloride challenge (17). Compared with acidotic cases, these patients tended to be younger, with lower plasma creatinines, better preservation of urinary concentrating ability, and less (or no) nephrocalcinosis; over the subsequent 10 years two of them (A:II:3 and A:II:8) spontaneously developed acidosis. Acidotic patients were treated with oral alkalis, usually six grams of sodium bicarbonate daily, and had normal acid-base status at the time of the present study; nonacidotic patients were not treated.

Urine acidification was assessed by urine $\mathrm{pH}$ during spontaneous acidosis, or in nonacidotic patients after acute ammonium chloride challenge (17); renal concentrating ability was tested as previously described (15). Blood films from all patients were carefully examined by experienced clinical hematologists, and none showed abnormal morphological features. However, red cell indices showed that A:II:3, A:II:6, A:II:8, B:II:4 and C:I:1, all with gross nephrocalcinosis, had erythrocytosis with raised hemoglobin and hematocrit values (17.0$18.2 \mathrm{~g} / \mathrm{dl}$ and $51.9-55 \%$, respectively), as has previously been described as a complication of gross nephrocalcinosis from various causes $(19,20)$.

\section{Linkage analysis}

Linkage studies were carried out with the microsatellite marker D17S759, previously shown (21) in the consensus map of chromosome 17 to map close to the $A E 1$ gene (also known as $S L C 4 A 1$ or $E P B 3)$. The sequence of primers required for this marker was obtained from the Genome Database. The marker was typed manually by incorporating trace amounts of ${ }^{32} \mathrm{P}$-labeled dCTP in the PCR reaction before separating the products on acrylamide gels and subsequent fluorography. The haplotypes were assigned arbitrary numbers as given in Fig. 1.

\section{Analysis of the AE1 gene by single-strand conformation polymorphisms and DNA sequencing}

Genomic DNA was isolated from frozen buffy coats prepared from blood samples (22). The coding regions of each of exons 2 to 20 (13) of the human $A E 1$ gene were analyzed for single-strand conformation

Table I. Clinical Details of dRTA Patients

\begin{tabular}{|c|c|c|c|c|c|c|c|c|c|}
\hline \multirow{4}{*}{$\begin{array}{c}\text { Case } \\
\text { number }\end{array}$} & \multicolumn{6}{|c|}{ At diagnosis } & & & \\
\hline & \multirow[b]{3}{*}{ Sex/age (yr) } & \multirow{2}{*}{\multicolumn{3}{|c|}{ Plasma }} & \multicolumn{2}{|c|}{ Urine } & \multicolumn{3}{|c|}{ Current status } \\
\hline & & & & & \multirow{2}{*}{$\begin{array}{c}\text { Minimum } \\
\mathrm{pH}\end{array}$} & \multirow{2}{*}{$\begin{array}{l}\text { Maximum } \\
\mathrm{mOsm} / \mathrm{kg}\end{array}$} & \multirow[b]{2}{*}{ Age (yr) } & \multirow{2}{*}{$\begin{array}{l}\text { Nephro- } \\
\text { calcinosis }\end{array}$} & \multirow[b]{2}{*}{ Kidney stones } \\
\hline & & Creatinine & $\mathrm{HCO}_{3}^{-}$ & $\mathrm{K}^{+}$ & & & & & \\
\hline & & umol/liter & $\mathrm{mmol} /$ liter & mmol/liter & & & & & \\
\hline A:I:1 & $\mathrm{F} / 60$ & 74 & 24 & 4.1 & 6.26 & 635 & 74 & - & + \\
\hline A:I:2 & $\mathrm{F} / 40$ & 86 & 18 & 3.4 & 6.35 & 572 & 71 & + & + \\
\hline A:I:3 & $\mathrm{F} / 44$ & 177 & 14 & 4.0 & 6.60 & n.t. & died 60 & + & - \\
\hline A:II:3 & $\mathrm{M} / 27$ & 115 & 23 & 3.1 & 6.45 & 525 & 47 & + & + \\
\hline A:II:5 & $\mathrm{F} / 35$ & 88 & 25 & 3.7 & 6.09 & 855 & 35 & - & - \\
\hline A:II:6 & $\mathrm{M} / 36$ & 104 & 19 & 3.0 & 6.59 & 354 & 50 & + & - \\
\hline A:II:8 & $\mathrm{M} / 34$ & 127 & 24 & 3.9 & 6.71 & 342 & 47 & + & + \\
\hline A:II:9 & $\mathrm{M} / 31$ & 92 & 23 & 3.8 & 6.35 & 626 & 41 & - & + \\
\hline A:III:1 & $\mathrm{M} / 9$ & 63 & 22 & 4.2 & 6.00 & 1100 & 16 & - & - \\
\hline A:III:2 & $\mathrm{F} / 6$ & 52 & 21 & 4.2 & 5.95 & 943 & 13 & - & - \\
\hline B:I:4 & $\mathrm{F} / 10$ & 97 & 17 & 2.1 & 6.60 & 252 & died 51 & + & + \\
\hline B:II:2 & $\mathrm{F} / 11$ & 95 & 21 & 4.0 & 6.23 & 360 & 43 & + & + \\
\hline B:II:3 & $\mathrm{F} / 8$ & 62 & 19 & 4.1 & 6.80 & 303 & 40 & + & + \\
\hline B:II:4 & $\mathrm{M} / 6$ & 54 & 18 & 3.5 & 6.23 & 712 & 38 & + & + \\
\hline C:I:1 & $\mathrm{M} / 22$ & 115 & 21 & 3.3 & 6.42 & 290 & 47 & + & + \\
\hline C:II:2 & $\mathrm{M} / 2$ & 67 & 15 & 3.0 & n.t. & n.t. & 2 & + & - \\
\hline D:I:1 & $\mathrm{M} / 27$ & 100 & 21 & 3.6 & 6.30 & n.t. & 64 & + & - \\
\hline D:II:2 & $\mathrm{F} / 19$ & 70 & 23 & 3.7 & 6.27 & 749 & 35 & + & - \\
\hline \multicolumn{10}{|l|}{ Normal } \\
\hline values & & $50-125$ & $22-31$ & $3.4-4.8$ & $<5.30$ & $>940$ & & & \\
\hline
\end{tabular}


polymorphisms (SSCP, 23) after polymerase chain reaction (PCR) amplification of genomic DNA in the presence of ${ }^{32} \mathrm{P}$-labeled dATP or dCTP $(3000 \mathrm{Ci} / \mathrm{mmol})$, using primers based on the sequences at the intron-exon junctions (12, gift of Dr. S. Lux). The protein coding region of exon 20 was amplified using the antisense primer AS44 (CCATGAGGTGCCCATGAACT) and a sense primer based on the DNA sequence at the $3^{\prime}$ end of intron 19 (13). SSCP was done using mutation detection enhancement (MDE) nondenaturing gels (AT Biochem, Malvern, PA) following the protocols provided by the manufacturer. DNA sequencing was carried out directly on both strands of PCR products using a Cycle sequencing kit (U.S. Biochemical Corp., Cleveland, OH), the Ampicycle (Perkin-Elmer Corp., Norwalk, CT) PCR sequencing kit and Sequagel XR sequencing solution (National Diagnostics, GA) or the Thermo Sequenase $\left[{ }^{33} \mathrm{P}\right]$ radiolabeled terminator cycle sequencing kit (Amersham International, Bucks, England).

PCR amplification and DNA sequencing of the putative kidney promoter and kidney translation initiator codons, in both dRTA and control samples, used primers designed to span the relevant areas in intron 3 and exon 4 of the $A E 1$ gene, as follows: KproS1: (sense; nucleotides [nts] 78 to 97 from the 5' end of intron 3); GASAnn 18: (antisense; nts 294 to 315 from the 5' end of intron 3); KProS4: (sense; nts 294 to 315 from the $5^{\prime}$ end of intron 3); KproAS1: (antisense; nts 589 to 609 from the $5^{\prime}$ end of intron 3); GS10 (sense; nts 466 to 485 from the $5^{\prime}$ end of intron 3); AS19 (antisense; nts 13 to 31 of exon 4).

\section{Analysis of the GPA gene by DNA sequencing}

The coding regions of each of exons 2 to 5 of the human GPA gene were amplified by PCR, using primers based on the intron-exon junctions (24) and sequences from the GenBank database (accession numbers M60707, M60708, M24132, L31856, L31358). DNA sequencing was carried out directly on both strands of PCR products as described above.

\section{Anion transport studies}

Sulfate transport assay. The $\left[{ }^{35} \mathrm{~S}\right]$ sulfate influx into red blood cells was measured using equal numbers of dRTA and control cells (determined using a cell counter) at $10 \%$ hematocrit, and the number of 4,4'-di-isothiocyanato-stilbene-2,2'-disulfonic acid (DIDS) binding sites was determined by titration of sulfate transport as described previously (25). The $V_{\max }$ and apparent $K_{\mathrm{m}}$ for $\left.{ }^{35} \mathrm{~S}\right]$ sulfate influx were calculated from sulfate influx measurements in the absence of DIDS, at sulfate concentrations between 0.4 and $40 \mathrm{mM}$.

Iodide transport assay. The $\left.{ }^{[25} \mathrm{I}\right]$ iodide influx into red blood cells was determined as above but in a $N$-[2-hydroxyethy]piperazine- $N^{\prime}-$ [2-ethanesulfonic acid] (Hepes) buffered citrate buffer $(50 \mathrm{mM}$ Hepes, 2 mM EGTA, 0.4-60 mM NaI, Na-citrate to 310 mosM, pH 7.4). Influx was measured over a 2 -min period at $0^{\circ} \mathrm{C}$.

Analysis of red blood cell membrane proteins and endoglycosidase treatment. Membranes were prepared from untreated or chymotrypsin-treated red cells (26). The membrane proteins were separated by SDS-PAGE using the method of Laemmli (27). Membranes from untreated or chymotrypsin-treated dRTA and control red cells were treated with peptide $\mathrm{N}$-glycosidase F (PNGase F) according to the manufacturer's instructions (New England Biolabs, Beverly, MA). The membranes were incubated for $10 \mathrm{~min}$ at $100^{\circ} \mathrm{C}$ in $0.5 \% \mathrm{SDS}, 1 \%$ $\beta$-mercaptoethanol, $0.2 \mathrm{mM} \mathrm{PMSF}$, and then for one hour at $37^{\circ} \mathrm{C}$ in 0.1 M sodium phosphate, $\mathrm{pH} 7.5,2 \%$ N P-40, 1000 U PNGase F. Samples were separated by SDS-PAGE as described above. Immunoblotting was performed as described by Wainwright et al. (14), using murine monoclonal antibody BRIC 155 , which is directed against the $\mathrm{COOH}$-terminal cytoplasmic tail of band 3 , or the monoclonal antiGPA antibodies described in the text.

\section{Preparation of mutant constructs}

BSXG1.B3, which contains the coding region of human erythrocyte AE1 cDNA between the $5^{\prime}$ and $3^{\prime}$ noncoding regions of the Xenopus $\beta$-globin cDNA (28), was used as a template for the construction of
$\operatorname{Arg}_{589} \rightarrow$ His (R589H), $\operatorname{Arg}_{589} \rightarrow$ Cys (R589C), and Ser $_{613} \rightarrow$ Phe (S613F) mutants. BSXG1.B3(R589H) was made using the Sculptor in vitro mutagenesis kit (Amersham Life Science, Arlington Heights, IL) according to the manufacturer's instructions using the mutagenic oligonucleotide CATGATGCTGCACAAGTTCAAGAAC. BSXG1.B3(R589C) was also made using Sculptor in vitro mutagenesis kit using the mutagenic oligonucleotide CCATGATGCTGTGCAAGTTCAAGAAC. BSXG1.B3(S613F) was constructed using the Seamless Cloning Kit (Stratagene USA, La Jolla, CA) according to the manufacturer's instructions. The oligonucleotides CCACCTCTTCATTCATCCTGATCATGGTCCTG and CCACCTCTTCAGAAGATGGGGACCCCGAAGT were used in the protocol to PCR amplify the whole of BSXG1.B3 and introduce the S613F mutation as described (29). BSXG1.KB3 encodes the kidney isoform of AE1 which lacks the first 65 codons of erythroid AE1, so that the translation product contains $\mathrm{Met}_{66}$ to the $\mathrm{COOH}$ terminus of erythroid AE1. BSXG1.KB3(R589H), BSXG1.KB3(R589C), and BSXG1.KB3(S613F), the kidney analogues of the erythroid AE1 mutants, were prepared by purifying the BstXI-XbaI fragments of the BSXG1.B3 mutants and substituting them for the corresponding fragments in BSXG1.KB3 (derived from a KB3 cDNA constructed by R. Beckmann, University of Bristol). The sequences of the entire protein coding regions of the constructs were confirmed to be correct using an ABI 377 DNA sequencer or using the Sequenase 2.0 DNA sequencing kit (USB) according to manufacturer's instructions.

\section{Expression of AE1 in Xenopus oocytes}

The methods used for the preparation of AE1 cRNA and its expression in Xenopus oocytes and the assay of chloride uptake into the oocytes have been described in detail previously $(28,30,31)$. In summary, capped cRNA was transcribed in vitro from the plasmids encoding the normal and mutant AE1s and kidney AE1s. Oocytes were injected with cRNA and allowed to express the protein for $24 \mathrm{~h}$. at $18^{\circ} \mathrm{C}$. Anion transport induced in the oocytes was measured by comparing the uptake of ${ }^{36} \mathrm{Cl}^{-}$over a 20 -min period by parallel groups of $8-15$ oocytes incubated in the presence and absence of 4,4'dinitro-2,2'-stilbene disulfonate (DNDS). The band 3-specific anion transport was estimated from the DNDS-sensitive chloride uptake into the oocytes.

\section{Results}

We examined the possibility that the erythroid $A E 1$ gene was altered in autosomal dominant familial dRTA by studying the genomic DNA and red cells of four families affected with the condition (Fig. 1, $A-D$ ). Family A had three generations affected with dRTA. Nine affected members of the family were studied, together with four unaffected family members in the second generation, two unaffected family members related by marriage (A:I:2 and A:II:10) and several unrelated normal individuals. Family B has been previously reported (16) to have dRTA in two generations ( $\mathrm{I}$ and II in Fig. 1). We examined three affected siblings in generation II and two unaffected siblings in generation III. Only small samples of blood were available from the two affected members in family $\mathrm{C}$ (Fig. 1), and they declined to give further blood samples which limited the red cell studies that could be done; the two other family members (C:II:1 and C:II:3) were unwilling to give samples for study. Two affected individuals in two generations of Family D were studied, together with four unaffected family members.

Linkage analysis. Families A, B, and D were large enough for linkage analysis. Linkage studies were carried out with the microsatellite marker D17S759, located close to the $A E 1$ gene on chromosome 17. Fig. 1 shows that the disease co-segregated with haplotype 3 in family A, haplotype 8 in family B and hap- 


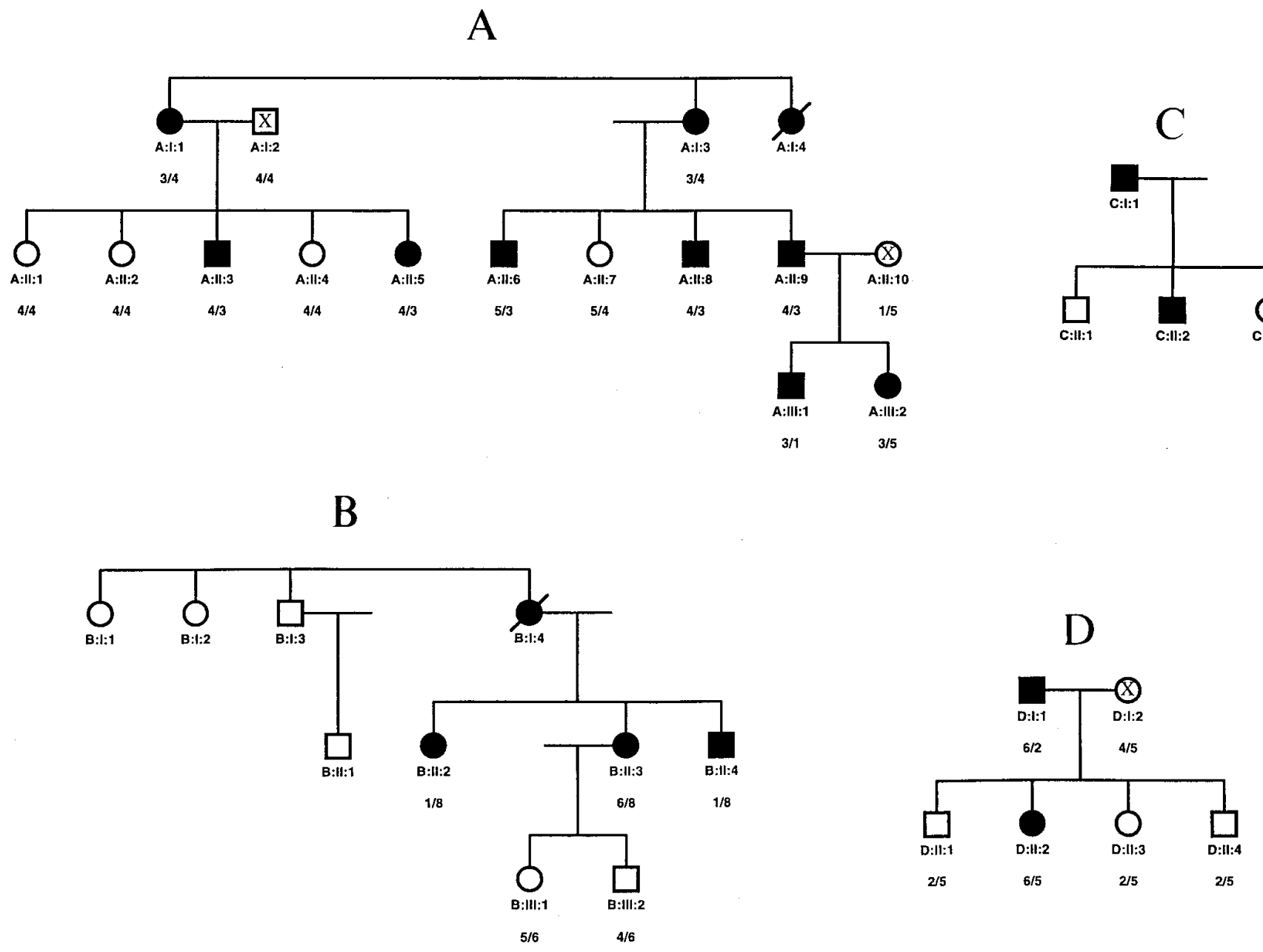

Figure 1. Family trees of dRTA patients examined in this study. $(\bullet, \mathbf{0})$ Clinical dRTA syndrome (complete or incomplete); ( $\bigcirc, \square)$ no clinical features of dRTA, urinary acidification studies refused by C:II:1, C:II:3 and D:II:1, but normal in all others shown; ( $\bigcirc$, $\square$ marked with X) unaffected spouses of dRTA patients, studied for linkage data. The numbers show the results of haplotyping with the marker D17S759 (arbitrary numbering).

lotype 6 in family D. The haplotyping results of all these families gave a lod score for dRTA vs D17S759 of +3.44 at theta $=$ 0 . DNA samples from affected members of the three different families were typed on the same gel and no alleles were found in common.

Mutations in the AE1 (band 3) gene associated with dRTA. We examined the genomic DNA of the members of the dRTA families for alterations in the $A E 1$ gene. The exons of the $A E 1$ gene were amplified using the polymerase chain reaction (PCR) and primers based on the $A E 1$ gene sequence (13). The exons were scanned for mutations by single-strand conformational polymorphism (SSCP) analysis or DNA sequencing on both strands (two or more samples from affected individuals) in comparison with samples from unaffected family members or controls.

DNA sequencing of exon 14 showed that all the affected members of family A were heterozygous for a $\mathrm{G} \rightarrow \mathrm{A}$ mutation in exon 14 of the $A E 1$ gene, at the position corresponding to $\mathrm{nt}$ 1766 of AE1 mRNA (numbered from the erythroid translation start codon). The mutation alters $\operatorname{Arg}_{589}$ of normal band 3 to His $(\mathrm{R} 589 \mathrm{H})$. The unaffected members of the dRTA family did not carry this mutation, and all were homozygous for the normal $A E 1$ gene sequence (Table II). No other changes were found in the $A E 1$ exons of the affected members of family A. Similar studies were carried out on the genomic DNA of family B. All the affected individuals of family B were found to be heterozygous for the same $\operatorname{Arg}_{589} \rightarrow$ His $(\mathrm{R} 589 \mathrm{H})$ mutation in the $A E 1$ gene as was found in the affected members of family A (Table III). The unaffected members of the family were homozygous for normal band 3 .

Studies on the genomic DNA of the affected individuals in family $\mathrm{C}$ showed that both were heterozygous for a $\mathrm{C} \rightarrow \mathrm{T}$ mutation at the position corresponding to nt 1765 of AE1 cDNA which results in a $\mathrm{Arg}_{589} \rightarrow$ Cys (R589C) change in band 3 (Table III). This arginine residue is changed to histidine in affected members of families $\mathrm{A}$ and $\mathrm{B}$, but here is mutated to cysteine. DNA from unaffected members of family $\mathrm{C}$ was not available for study.

The affected individuals in family $\mathrm{D}$ were also found to be heterozygous for a mutation in band 3, but the amino acid altered was different from that associated with the disease in families A, B, and C. Both affected individuals in family D 
Table II. Red Cell Sulfate Transport, DIDS Binding Sites and Band 3 Sequence of Family A

\begin{tabular}{|c|c|c|c|c|c|c|}
\hline $\begin{array}{l}\text { Family } \\
\text { member }\end{array}$ & $\begin{array}{l}\text { dRTA } \\
\text { status }\end{array}$ & $\begin{array}{l}\text { Sulphate transport } \\
\text { activity (percent } \\
\text { of normal) }\end{array}$ & $\begin{array}{l}\text { Number of DIDS } \\
\text { binding sites (per- } \\
\text { cent of normal) }\end{array}$ & $K_{\mathrm{m}}($ percent of normal $)$ & $V_{\max }$ (percent of normal) & $\begin{array}{c}\text { Altered amino } \\
\text { acid residue } \\
\text { in band } 3\end{array}$ \\
\hline A:I:1 & dRTA & $74 \pm 1^{\|}$ & 94 & $115 \pm 7 *$ & $90 \pm 2 *$ & $\mathrm{R} 589 \rightarrow \mathrm{H}$ \\
\hline A:I:2 & Normal & $99 \pm 2 *$ & 100 & $106 \pm 4 *$ & $105 \pm 2 *$ & R589 \\
\hline A:I:3 & dRTA & $83 \pm 2^{\S}, 75 \pm 2^{\S}, 80 \pm 4^{\S}$ & $94,95,108$ & $136 \pm 6 \|, 144 \pm 11^{\S}$ & $103 \pm 6^{*}, 109 \pm 4^{*}$ & $\mathrm{R} 589 \rightarrow \mathrm{H}$ \\
\hline A:II:1 & Normal & $92 \pm 2^{\ddagger}$ & 97 & $92 \pm 4 *$ & $92 \pm 3^{*}$ & R589 \\
\hline A:II:2 & Normal & $97 \pm 1 *$ & 89 & $100 \pm 6^{*}$ & $103 \pm 3 *$ & R589 \\
\hline A:II:3 & dRTA & $72 \pm 2^{\|}, 74 \pm 2^{\|}$ & 101,95 & $118 \pm 9 *$ & $93 \pm 3^{*}$ & $\mathrm{R} 589 \rightarrow \mathrm{H}$ \\
\hline A:II:4 & Normal & $96 \pm 1 *$ & 96 & $96 \pm 4 *$ & $94 \pm 3 *$ & R589 \\
\hline A:II:5 & dRTA & $76 \pm 1^{\|}$ & 93 & $123 \pm 14 *$ & $97 \pm 4 *$ & $\mathrm{R} 589 \rightarrow \mathrm{H}$ \\
\hline A:II:6 & dRTA & $72 \pm 5^{\ddagger}, 79 \pm 4^{\S}$ & 101,102 & $118 \pm 11^{*}, 143 \pm 7 \|$ & $91 \pm 5^{*}, 101 \pm 3^{*}$ & $\mathrm{R} 589 \rightarrow \mathrm{H}$ \\
\hline A:II:7 & Normal & $95 \pm 4 *, 94 \pm 3 *$ & 104,100 & $90 \pm 6^{*}$ & $91 \pm 5 *$ & R589 \\
\hline A:II:8 & dRTA & $81 \pm 3^{\S}$ & 106 & $127 \pm 6\left\|, 131 \pm 5^{\S}, 144 \pm 7\right\|$ & $93 \pm 5^{*}, 102 \pm 5^{*}, 107 \pm 3^{*}$ & $\mathrm{R} 589 \rightarrow \mathrm{H}$ \\
\hline A:II:9 & dRTA & $72 \pm 3^{\|}, 74 \pm 3^{\S}, 74 \pm 3^{\|}$ & $90,97,100$ & $140 \pm 7^{\|}, 133 \pm 8^{\S}$ & $99 \pm 3^{*}, 102 \pm 5^{*}$ & $\mathrm{R} 589 \rightarrow \mathrm{H}$ \\
\hline A:II:10 & Normal & $95 \pm 3 *$ & 93 & $112 \pm 3 *$ & $101 \pm 5^{*}$ & R589 \\
\hline A:III:1 & dRTA & $69 \pm 2^{\|}, 79 \pm 4^{\S}$ & 103,97 & $128 \pm 6^{\|}$ & $91 \pm 3 *$ & $\mathrm{R} 589 \rightarrow \mathrm{H}$ \\
\hline A:III:2 & dRTA & $77 \pm 4 \|$ & 96 & $129 \pm 7^{\S}$ & $94 \pm 3 *$ & $\mathrm{R} 589 \rightarrow \mathrm{H}$ \\
\hline \multicolumn{2}{|c|}{ Mean affected (dRTA) } & $76 \pm 4, n=16$ & $98 \pm 5, n=16$ & $131 \pm 10, n=14$ & $98 \pm 6, n=14$ & \\
\hline \multicolumn{2}{|c|}{ Mean unaffected } & $95 \pm 2, n=7$ & $97 \pm 5, n=7$ & $99 \pm 8, n=6$ & $98 \pm 6, n=6$ & \\
\hline
\end{tabular}

Sulfate transport activity, number of DIDS binding sites and apparent $K_{\mathrm{m}}$ and $V_{\max }$ for sulfate transport were determined as described in the legends to Figs. $2 a$ and $3 a$, respectively. Each value is the mean and standard error of the mean expressed as the percentage of the mean value obtained for the normal control cells in the experiment and was obtained by regression analysis of the data. Samples from some subjects were studied more than once. Statistical analysis of the significance of the difference between the results for the family samples and control samples was done using an unpaired, two-tailed Student's $t$ test on the two sets of data. The results of the statistical analysis are indicated by the following symbols: ${ }^{*} P>0.05 ;{ }^{\ddagger} P<$ $0.05>0.01 ;{ }^{\S} P<0.01>0.001 ;{ }^{\|} P \leq 0.001$. n.t. , not tested; $R$, arginine; $H$, histidine.

were heterozygous for a $\mathrm{C} \rightarrow \mathrm{T}$ mutation in exon 15 at the position corresponding to nt 1838 of AE1 cDNA, which results in the amino acid change $\operatorname{Ser}_{613} \rightarrow$ Phe $(\mathrm{S} 613 \mathrm{~F})$. The unaffected family members were all homozygous for the normal AE1 sequence (Table IV).

We also examined the possibility that changes in the kidney promoter of the $A E 1$ gene of the affected members of these families might specifically reduce the transcription of kidney AE1 in these individuals without affecting red cell AE1 expression. We sequenced a 913 bp region of the $A E 1$ gene (13) containing the consensus transcription factor binding sites upstream of the kidney promoter, TATA box and downstream sequence (extending from nt 78 from the $5^{\prime}$ end of erythroid intron 3 to nt 31 from the $5^{\prime}$ end of erythroid exon 4) of af-

Table III. Red Cell Sulfate Transport, DIDS Binding Sites and Band 3 Sequence of Families B and C

\begin{tabular}{|c|c|c|c|c|c|c|}
\hline $\begin{array}{l}\text { Family } \\
\text { member }\end{array}$ & $\begin{array}{l}\text { dRTA } \\
\text { status }\end{array}$ & $\begin{array}{l}\text { Sulphate transport } \\
\text { activity (percent } \\
\text { of normal) }\end{array}$ & $\begin{array}{l}\text { Number of DIDS } \\
\text { binding sites } \\
\text { (percent of normal) }\end{array}$ & $\begin{array}{c}K_{\mathrm{m}} \text { (percent } \\
\text { of normal) }\end{array}$ & $\begin{array}{c}V_{\max } \text { (percent } \\
\text { of normal) }\end{array}$ & $\begin{array}{c}\text { Altered amino } \\
\text { acid residue } \\
\text { in band } 3\end{array}$ \\
\hline B:II:2 & dRTA & $80 \pm 3^{\|}$ & 94 & $125 \pm 7^{\ddagger}$ & $101 \pm 3 *$ & $\mathrm{R} 589 \rightarrow \mathrm{H}$ \\
\hline B:II:3 & dRTA & $79 \pm 1^{\|}, 80 \pm 5^{\ddagger}$ & 107,99 & $120 \pm 3^{\ddagger}$ & $96 \pm 1 *$ & $\mathrm{R} 589 \rightarrow \mathrm{H}$ \\
\hline B:II:4 & dRTA & $80 \pm 4 \|, 74 \pm 6^{\ddagger}$ & 97,88 & $130 \pm 4 \|$ & $98 \pm 1 *$ & $\mathrm{R} 589 \rightarrow \mathrm{H}$ \\
\hline B:III:1 & Normal & $93 \pm 6^{*}, 97 \pm 5^{*}$ & 103,97 & $94 \pm 4 *$ & $95 \pm 2 *$ & R589 \\
\hline B:III:2 & Normal & $95 \pm 5 *$ & 102 & (n.t.) & (n.t.) & R589 \\
\hline \multicolumn{2}{|c|}{ Mean affected (dRTA) } & $79 \pm 3, n=5$ & $97 \pm 7, n=5$ & $125 \pm 5, n=3$ & $98 \pm 3, n=3$ & \\
\hline \multicolumn{2}{|c|}{ Mean unaffected } & $95 \pm 2, n=3$ & $101 \pm 3, n=3$ & 94 & 95 & \\
\hline C:I:1 & dRTA & $78 \pm 2 \|$ & 108 & (n.t.) & (n.t.) & $\mathrm{R} 589 \rightarrow \mathrm{C}$ \\
\hline C:II:2 & dRTA & $82 \pm 3^{\|}$ & 104 & (n.t.) & (n.t.) & $\mathrm{R} 589 \rightarrow \mathrm{C}$ \\
\hline \multicolumn{2}{|c|}{ Mean affected (dRTA) } & 80 & 106 & & & \\
\hline
\end{tabular}

Sulfate transport activity, DIDS binding sites and apparent $K_{\mathrm{m}}$ and $V_{\max }$ for sulfate transport were determined as described in the legends to Figs. $2 a$ and $3 a$ and Table II. Samples from some subjects were studied more than once. Symbols for the results of statistical analysis are described in Table II. $C$, cysteine. 
Table IV. Red Cell Sulfate Transport, DIDS Binding Sites and Band 3 Sequence of Family D

\begin{tabular}{|c|c|c|c|c|c|c|}
\hline $\begin{array}{l}\text { Family } \\
\text { member }\end{array}$ & $\begin{array}{l}\text { dRTA } \\
\text { status }\end{array}$ & $\begin{array}{l}\text { Sulphate transport } \\
\text { activity (percent } \\
\text { of normal) }\end{array}$ & $\begin{array}{l}\text { Number of DIDS } \\
\text { binding sites } \\
\text { (percent of normal) }\end{array}$ & $\begin{array}{c}K_{\mathrm{m}} \text { (percent } \\
\text { of normal) }\end{array}$ & $\begin{array}{c}V_{\max }(\text { percent } \\
\text { of normal) }\end{array}$ & $\begin{array}{l}\text { Altered amino } \\
\text { acid residue } \\
\text { in band } 3\end{array}$ \\
\hline D:I:1 & dRTA & $252 \pm 5^{\|}, 273 \pm 8^{\|}$ & 110,109 & $27 \pm 1^{\|}$ & $74 \pm 2^{\|}$ & $\mathrm{S} 613 \rightarrow \mathrm{F}$ \\
\hline D:I:2 & Normal & $106 \pm 4 *$ & 102 & (n.t.) & (n.t.) & S613 \\
\hline D:II:1 & Normal & (n.t.) & (n.t.) & (n.t.) & (n.t.) & S613 \\
\hline D:II:2 & dRTA & $246 \pm 6\|, 275 \pm 9\|$ & 109,105 & $29 \pm 2^{\|}$ & $75 \pm 2 \|$ & $\mathrm{S} 613 \rightarrow \mathrm{F}$ \\
\hline D:II:3 & Normal & $108 \pm 3^{*}, 102 \pm 5^{*}$ & 109,100 & $96 \pm 2 *$ & $95 \pm 2 *$ & S613 \\
\hline D:II:4 & Normal & $102 \pm 1 *, 97 \pm 5^{*}$ & 106,100 & $96 \pm 4 *$ & $93 \pm 2 *$ & S613 \\
\hline \multicolumn{2}{|c|}{ Mean affected (dRTA) } & $262 \pm 15, n=4$ & $108 \pm 2, n=4$ & 28 & 74.5 & \\
\hline \multicolumn{2}{|c|}{ Mean unaffected } & $103 \pm 4, n=5$ & $103 \pm 4, n=5$ & 96 & 94 & \\
\hline
\end{tabular}

Sulfate transport activity, DIDS binding sites and apparent $K_{\mathrm{m}}$ and $V_{\max }$ for sulfate transport were determined as described in the legends to Figs. $2 a$ and $3 a$ and Table II. Samples from some subjects were studied more than once. Symbols for the results of statistical analysis are described in Table II. $S$, serine; $F$, phenylalanine.

fected and unaffected members of the families. Although individuals in some of the families were heterozygous for a $\mathrm{g} \rightarrow \mathrm{a}$ mutation $332 \mathrm{nts}$. from the $5^{\prime}$ boundary of intron 3 , the presence of this mutation did not correlate with the disease. Thus while the unaffected individuals B:III:1 and D:II:3 and the dRTA patient D:I:1 were heterozygous for this mutation, the dRTA individuals A:I:3 and B:II:2 were homozygous for the normal sequence, as was the unaffected individual A:II:7 (see Fig. 1).

Anion transport properties of the red cells of $d R T A$ individuals. The influx of $\left[{ }^{35} \mathrm{~S}\right]$ sulfate into the red cells of the members of each family was compared with that of red cells from normal control individuals bled at the same time. The results for family A are summarized in Table II. Typical results obtained from di-isothiocyanatostilbene disulfonate (DIDS) titration studies of sulfate transport are shown in Fig. $2 a$. The samples from the affected family members showed a consistently lower anion transport activity than the normal samples at each concentration of DIDS. Under the conditions used for the assay the very high affinity inhibitor DIDS stoichiometrically binds band 3 and titrates anion transport, so that the intercept with the sulfate influx axis measures the relative transport activity, while the intercept with the DIDS concentration axis measures the number of DIDS binding sites in the cells and hence the relative number of band 3 molecules in the red cell samples (25). The dRTA and normal control samples had similar numbers of band 3 molecules per red cell (Table II). The reduction in the sulfate transport into the red cells of the different dRTA individuals compared with the normal control samples measured at the same time was consistently observed in several experiments conducted on different occasions $(76 \pm 4 \%$ [mean $\pm \mathrm{SEM}] ; n=16)$, while the combined results from these experiments showed there was no difference in the number of band 3 molecules in the red cells of the dRTA and normal control red cells $(98 \pm 5 \% ; n=16)$. In contrast the unaffected members of the family did not show a consistent difference in anion transport from the normal controls (Table II) and the mean value obtained from several experiments was $95 \pm 2 \%(n=7)$ of the control values. As expected the results of the DIDS titration experiments in Table II also show that the unaffected members of the family had levels of red cell band 3 which did not differ significantly from control normal red cells $(97 \pm 5 \% ; n=7)$.

Because of the very high affinity of DIDS for band 3, the conditions used for the experiment in Fig. $2 a$ cannot be used to examine whether there are small changes in the sensitivity of band 3 in dRTA red cells to stilbene disulfonate inhibitors (25). We therefore examined the sensitivity of sulfate transport in dRTA red cells to inhibition by the lower affinity inhibitor, 4-acetamido-4' -isothio-cyano-2,2' -stilbene disulfonate (SITS), using red cells from patient A:II:8 and normal red cells. Although the dRTA red cells showed a lower uptake of sulfate than the control red cells when the same concentrations of SITS were present, the percentage inhibition of sulfate transport was found to be the same for the dRTA and control red cells over a range of SITS concentrations (data not shown).

The apparent $K_{\mathrm{m}}$ and $V_{\max }$ for sulfate transport of the red cells of affected and unaffected members of family A were measured in comparison with normal controls bled at the same time and are summarised in Table II. Typical results are shown in Fig. $3 a$. The red cells from the three affected individuals examined in this experiment showed a similar increase in apparent $K_{\mathrm{m}}$, but $V_{\max }$ values very close to the control. The mean of the results obtained with different family members (Table II) in several different experiments showed that the affected family members had an increase in the apparent $K_{\mathrm{m}}$ for sulfate to $131 \pm 10 \%(n=14)$ of the control samples measured at the same time, while the unaffected family members had normal $K_{\mathrm{m}}$ for sulfate (99 $\pm 8 \%$ of control; $n=6$ ). The mean of the $V_{\max }$ values obtained for the affected family members was $98 \pm 6 \%$ of the controls $(n=14)$, and for the unaffected family members was $98 \pm 6 \%$ of the controls $(n=6)$, suggesting that this kinetic parameter is unchanged in both the affected and unaffected individuals in family A. The unaffected family members had kinetic constants that were not significantly different from the control red cells.

Similar sulfate transport experiments were carried out on the red cells of family B and the results are summarised in Table III. The results of DIDS titration on some affected and unaffected family members and control red cells are shown in Fig. $2 b$. The mean of several experiments showed that the affected family members had sulfate transport reduced to 
a)

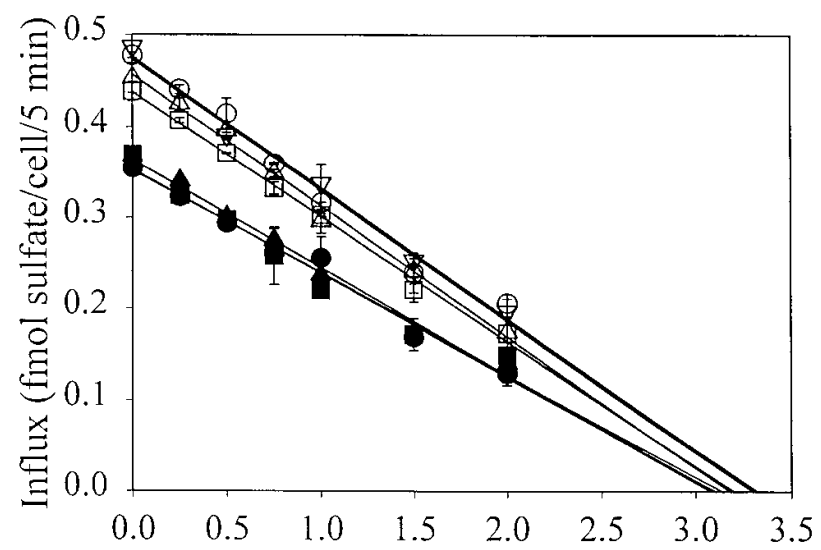

c)

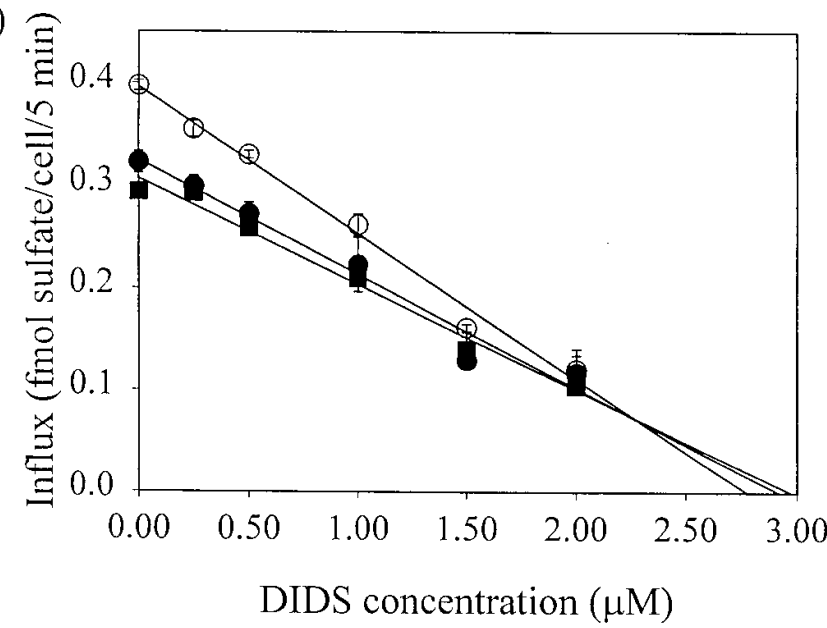

b)

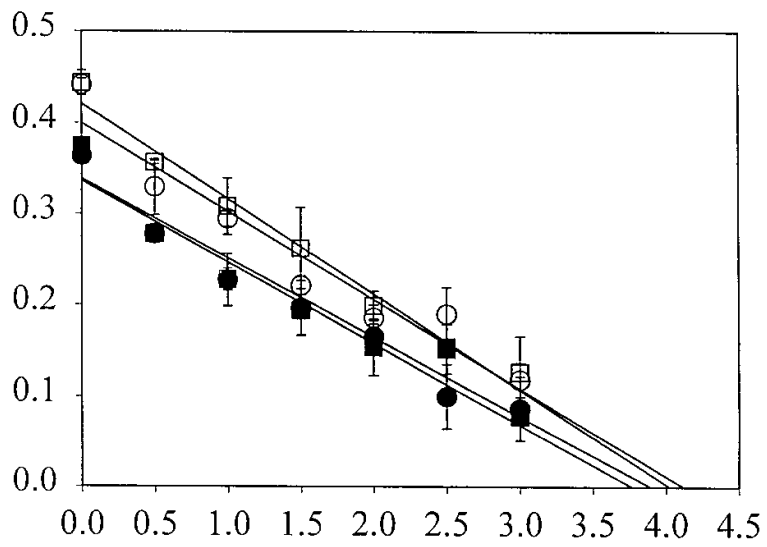

d)

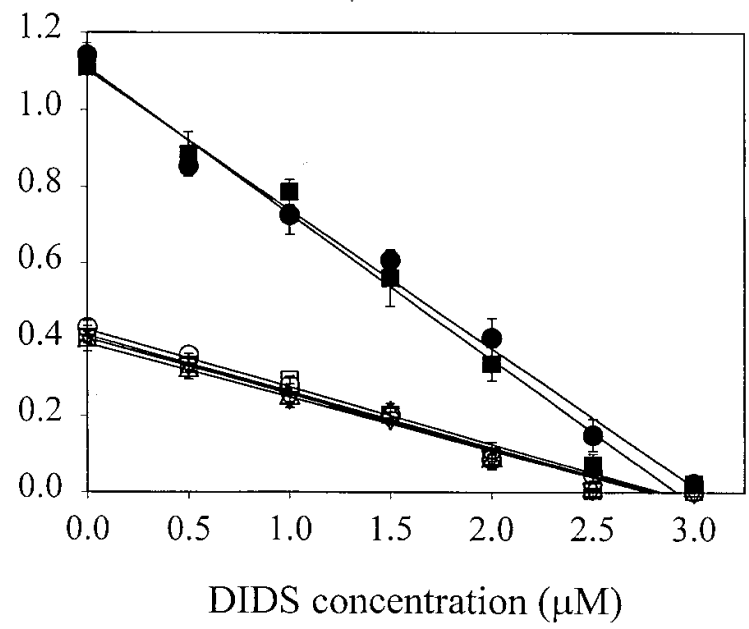

Figure 2. DIDS titration of sulfate influx into dRTA and normal samples. The influx of $\left[{ }^{35} \mathrm{~S}\right]$ sulfate into the cells was measured at $10 \%$ hematocrit in isotonic citrate buffer ( $84 \mathrm{mM}$ sodium citrate, $1 \mathrm{mM}$ EGTA pH 6.5) containing $4 \mathrm{mM}$ sodium sulfate. Influx was determined after 5 min at a nominal temperature of $30^{\circ} \mathrm{C}$ in the presence of different concentrations of DIDS as described previously (25). Each data point was derived from measurements in triplicate. The standard deviation is indicated by the error bars on the points. The lines show the results of linear regression analysis of the data. The results of statistical analysis of this data are included in Tables II-IV. Representative examples of experiments on samples from each family are shown. The results of the experiments in a, b, c and d are not directly comparable as each experiment was done un-

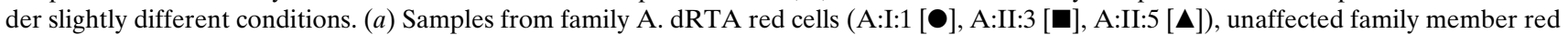

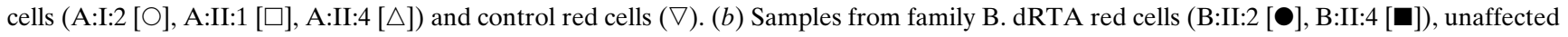

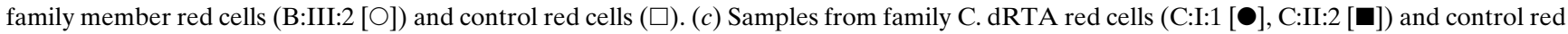
cells $(\bigcirc)$. (d) Samples from family D. dRTA red cells (D:I:1 [@], D:II:2 [ [ ] ]), unaffected family member red cells (D:I:2 [O], D:II:3 [ $\square$ ], D:II:4 $[\triangle])$ and control red cells $(\nabla)$.

$79 \pm 3 \%(n=5)$ of control red cells, but had similar band 3 content $(97 \pm 7 \% ; n=5)$ as the control red cells. The red cells of the affected individuals had an increased apparent $K_{\mathrm{m}}$ for sulfate but normal $V_{\max }$ (Table III and Fig. $3 b$ ). The red cells of the unaffected family members had sulfate transport and band 3 content similar to the normal control cells and the kinetic constants of the one unaffected family member tested were similar to the normal controls (Table III and Figs. $2 b$ and $3 b$ ).

Limited sulfate transport data were obtained from the red cells of the two affected members of family $\mathrm{C}$, because of the small samples of blood available. DIDS titration (Fig. $2 c$ and Table III) showed that the red cells of both affected individuals had reduced sulfate transport (mean $80 \%$ of control), and band 3 contents similar to the normal control.

The red cells of the affected members of family D showed sulfate transport characteristics which were quite different from those of the red cells of the other families studied. The two affected individuals had a striking increase in sulfate transport activity (Fig. $2 d$ and Table IV). The mean of several experiments showed that the dRTA red cells had sulfate transport increased by $262 \pm 15 \%(n=4)$ compared with the normal controls and band 3 content not significantly different from the controls $(108 \pm 2 \% ; n=4)$. Measurement of the kinetic constants for sulfate transport (Fig. $3 c$ and Table IV) showed that the red cells of the affected individuals had a marked reduction in the apparent $K_{\mathrm{m}}$ for sulfate (mean $28 \%$ of control) as well as a smaller reduction in the $V_{\max }$ for transport (mean $74.5 \%$ of control), suggesting that the increased transport activity of the dRTA cells results from a much increased affinity for sulfate. The red cells of the unaffected family members had normal sulfate transport, band 3 content and normal kinetic constants (Fig. $2 d$, Fig. $3 c$, and Table IV).

There are differences in the mechanism by which monovalent and divalent anions are transported by band 3 (ref. 32), 
a)

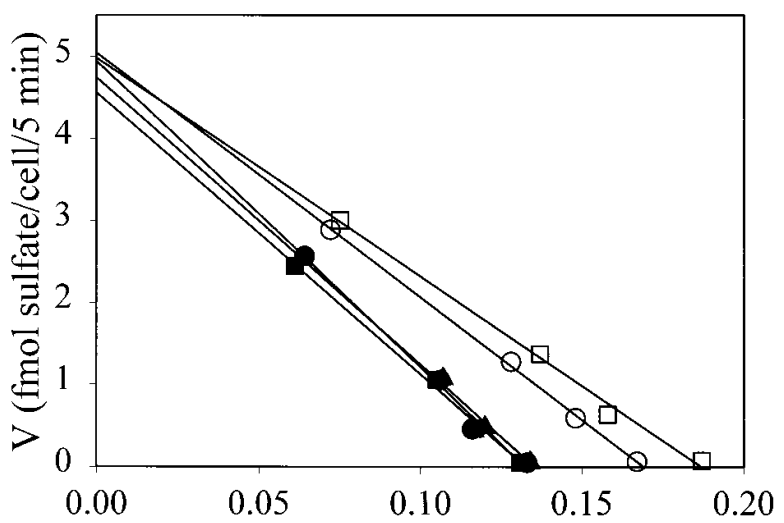

b)

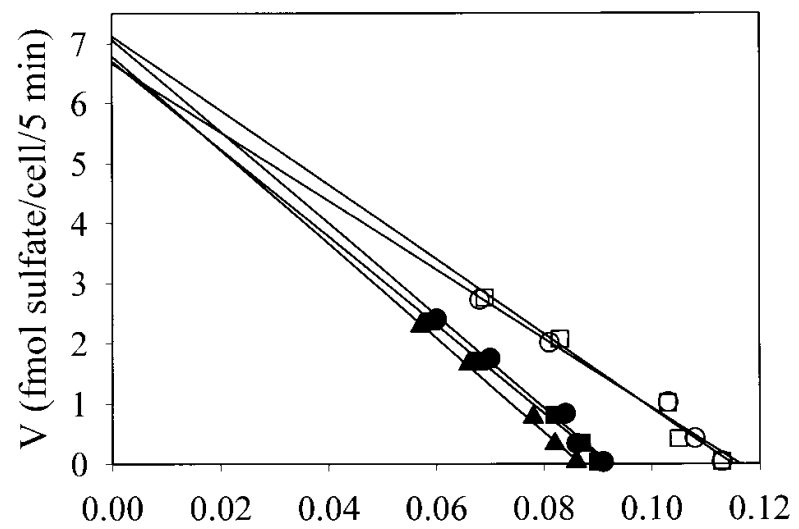

c)

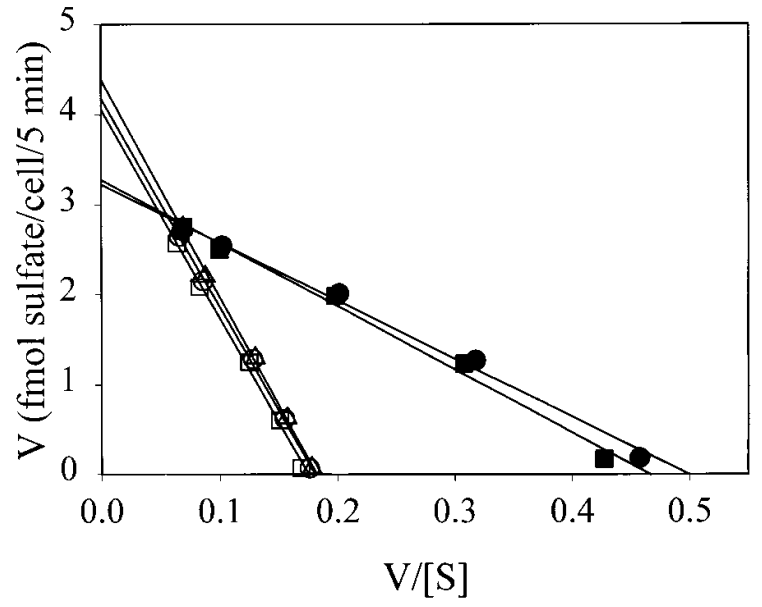

Figure 3. Sulfate influx into dRTA and normal red cells. The influx of $\left[{ }^{35} \mathrm{~S}\right]$ sulfate into the red cells was measured at $10 \%$ hematocrit in isotonic citrate buffer $\mathrm{pH} 6.5$ containing sodium sulfate concentrations between 40 and $0.4 \mathrm{mM}$. The tonicity of the buffer was maintained constant by varying the concentration of sodium citrate. Sulfate influx was determined after $5 \mathrm{~min}$ at a nominal temperature of $30^{\circ} \mathrm{C}$. Each data point was derived from measurements in triplicate. The results are presented as Eadie-Hofstee plots with linear regression analysis of the data. The results of statistical analysis of this data are included in Tables II-IV. Representative examples of experiments on samples from each family are shown. The results of the experiments in a, b, and c are not directly comparable as each experiment was done under slightly different conditions. (a) Samples from

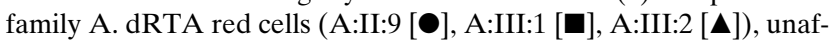
fected family member red cells (A:II:10 [O]) and control red cells ( $\square$ ). (b) Samples from family B. dRTA red cells (B:II:2 [0], B:II:3

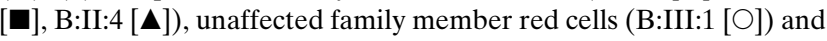
control red cells $(\square)$. (c) Samples from family D. dRTA red cells and it was desirable to examine whether the red cells of the affected members of family D showed a similar marked increase in monovalent anion transport. Since chloride uptake into red cells is too rapid to be conveniently measured, we measured the uptake of the more slowly transported anion, iodide, at $0^{\circ} \mathrm{C}$ to estimate the monovalent anion transport activity in the cells (Fig. 4). Although there appeared to be a small increase in iodide uptake into the dRTA cells, resulting from a small but significant increase in the $V_{\max }$ for iodide transport to $125 \%$ of the control, there was no change in the $K_{\mathrm{m}}$ for iodide, in contrast to the substantial change in the $K_{\mathrm{m}}$ for sulfate. The red cells of the affected individuals in family D thus show very different changes in transport characteristics for sulfate compared with iodide.

Band 3 in the $d R T A$ red cell samples from some families has an altered mobility on SDS-PAGE. When the red cell membrane proteins of the dRTA patients from families A, B, and C were compared with normal controls after separation on SDSPAGE, the mobility of band 3 was slightly slower in the dRTA samples compared with normal controls. The results for three affected family members from family A are shown in Fig. $5 a$. The change in mobility is particularly noticeable when the mobilities of the leading edge of band 3 of the dRTA and normal samples are compared. All the affected members of family A showed a similar shift in mobility. Band 3 of unaffected members of family A all had normal mobility, with the exception of A:II:7 whose red cells showed a shift in mobility similar to that observed for the affected family members. SSCP analysis and DNA sequencing confirmed that A:II:7 had normal band 3 sequence and the red cells of A:II:7 showed normal anion transport (Table II).

The relatively common band 3 polymorphism, band 3 Memphis (6), has a lower mobility than normal band 3 on SDS-PAGE (33), and it was important to establish that the abnormal mobility of dRTA band 3 did not result from the presence of this polymorphism. Band 3 Memphis can be readily distinguished from normal band 3 by chymotrypsin treatment of intact red cells. The resulting $\mathrm{NH}_{2}$-terminal proteolytic fragment of band 3 migrates as a sharp $60-\mathrm{kD}$ band in the case of normal band 3, but band 3 Memphis yields a fragment significantly larger (63 kD; ref. 33). Chymotrypsin treatment of the red cells of all the members of all the families (including the unaffected members) gave only the normal $60-\mathrm{kD} \mathrm{NH}_{2}$-terminal chymotrypsin fragment of band 3 (data not shown).

Since the $\mathrm{NH}_{2}$-terminal $60-\mathrm{kD}$ chymotrypsin fragment was the same size in both affected and unaffected members of the family, we studied the $\mathrm{COOH}$-terminal $35-\mathrm{kD}$ chymotrypsin fragment to further localize the origin of the shift in SDSPAGE mobility found in the intact band 3 of the dRTA samples. Changes in SDS-PAGE mobility might also be expected to be accentuated in this smaller fragment. It is difficult to detect the rather diffuse $35-\mathrm{kD}$ fragment band in Coomassie Blue-stained gels of erythrocyte membranes, so the fragment was visualized by immunoblotting using monoclonal antibody BRIC 155, which reacts with the COOH terminus of band 3 (14). Immunoblots using BRIC 155 of membranes from chymotrypsin-treated red cells, showed that the leading edge of the $35-\mathrm{kD}$ fragment of band 3 from the affected members of

(D:I:1 [@], D:II:2 [ $]$ ), unaffected family member red cells (D:II:3 [O], D:II:4 $[\square])$ and control red cells $(\triangle)$. 


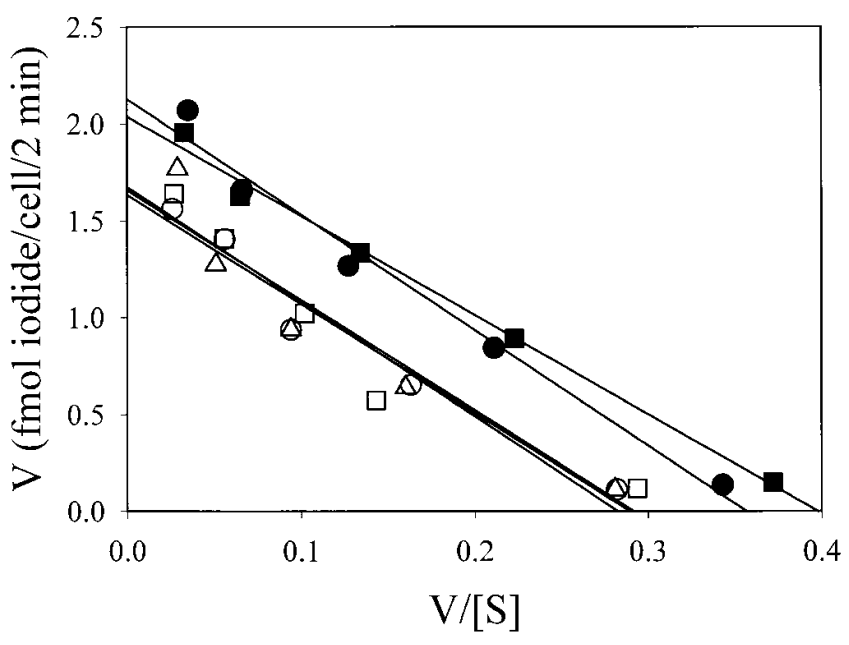

Figure 4. Iodide influx into red cells of family D and normal red cells. The influx of [ $\left.{ }^{125} \mathrm{I}\right]$ iodide into the red cells was measured at $10 \%$ hematocrit in isotonic citrate buffer $\mathrm{pH} 7.4$ containing between 60 and $0.4 \mathrm{mM}$ sodium iodide, with the tonicity of the buffer kept constant by varying the sodium citrate concentration. Iodide influx was determined after $2 \mathrm{~min}$ at $0^{\circ} \mathrm{C}$. Each data point was measured in triplicate. The results are presented as Eadie-Hofstee plots with linear regression analysis of the data. Family D dRTA red cells (D:I:1 [0], D:II:2 [ם]), unaffected family D member red cells (D:II:4 [O]) and two control red cells $(\square, \triangle)$. The $V_{\max }$ determined for the affected family members D:I: 1 and D:II:2 were $128 \pm 6 \%$ and $122 \pm 3 \%$, respectively, of the control red cells $(P<0.05$ and $>0.01$ for both samples), with $K_{\mathrm{m}} 103 \pm 8 \%$ and $88 \pm 4 \%$, respectively, of the control red cells $(P>$ 0.5 for both samples). The $V_{\max }$ and $K_{\mathrm{m}}$ of the unaffected family member D:II:4 were $98 \pm 6 \%$ and $97 \pm 11 \%$, respectively, of the control red cells (both with $P>0.5$ ). The $P$ values were determined using an unpaired, two-tailed Students $t$ test on the difference between the data from the family samples and the control sample data.

family A migrated more slowly than the normal controls or the unaffected family members (Fig. 5, $b$ and $c$ ). The distribution of material within the broad $35-\mathrm{kD}$ fragment band in the samples from affected individuals was also different from the normal controls or unaffected members of the family. However as noted above, the $35-\mathrm{kD}$ band 3 fragment from the unaffected individual A:II:7 was exceptional in that it showed a shifted mobility similar to that of the affected family members (Fig. $5 b$ ).

The $35-\mathrm{kD}$ band 3 chymotrypsin fragment of the affected members in families $\mathrm{B}$ and $\mathrm{C}$ showed a shift in mobility similar to that observed with the affected members of family A (Fig. 5, $d$ and $e$ ), while the $35-\mathrm{kD}$ fragment from the unaffected members of family B showed normal mobility. No samples were available from the unaffected members of family $C$.

In contrast to the results with families $\mathrm{A}, \mathrm{B}$, and $\mathrm{C}$, the red cell membranes of both affected and unaffected members of family D showed no abnormality in the mobility of the intact band 3 or the $35-\mathrm{kD}$ band 3 fragment of band 3 (data not shown).

Endoglycosidase treatment of red cells of the dRTA families. Band 3 carries a single, extensively branched N-glycan chain. The size of the carbohydrate chain is very heterogeneous because varying numbers of $\mathrm{N}$-acetyllactosamine repeat units are present in individual chains (34), and this size variation gives rise to the characteristic diffuse migration of band 3 on SDS-PAGE. The N-glycan chain is located on $\mathrm{Asn}_{642}$ in the $\mathrm{COOH}$-terminal $35-\mathrm{kD}$ fragment produced by chymotrypsin digestion of red cells. We determined whether the altered mobility of the dRTA band 3 in families A, B, and C resulted from alterations in the $\mathrm{N}$-glycan chain by examining the effect of digestion by PNGase F on the mobility of band 3. Endoglycosidase treatment of detergent-solubilized membranes from chymotrypsin treated red cells gave a sharp 35-kD fragment band with the same mobility in both affected and unaffected members and normal control samples in all the families (Fig. 5, $f-i$ ). This result suggests that the abnormal SDS-PAGE mobility of the dRTA band 3 in families A, B, and C results from an alteration in the $\mathrm{N}$-glycan chain. As expected both affected and unaffected samples gave the same sharp 35-kD band as normal samples when PNGase F digestion was done on the chymotrypsin-treated red cells of family D (results not shown).

The dRTA families have normal red cell glycophorin $A$ $(G P A)$. The band 3 in red cells which lack glycophorin A (En[a-] or $\mathrm{M}^{\mathrm{k}} / \mathrm{M}^{\mathrm{k}}$ red cells) shows an increased relative molecular mass on SDS-PAGE because its N-glycan chain is on average longer than the $\mathrm{N}$-glycan chain of band 3 from normal red cells (35-37). We immunoblotted dRTA red cell membranes with murine monoclonal antibody R1.3 which detects both glycophorin A (GPA) and glycophorin B, and two monoclonal antibodies directed to different epitopes on glycophorin A (R18 and BRIC 163), to eliminate the possibility that the altered oligosaccharide chain in dRTA resulted from an abnormality in glycophorin A. The erythrocyte membranes from two dRTA samples from family A (A:I:3 and A:II:9) as well as the unaffected member with abnormal band 3 mobility (A:II:7) gave the normal pattern of immunostaining with all three antibodies, showing that all these red cells contained normal GPA and glycophorin B (results not shown). All the remaining affected and unaffected members of families A, B, and D and C:I:1 were shown to have normal GPA by immunoblotting with BRIC 163 (data not shown). DNA sequencing of exons 2, 3, 4 and 5 of the GPA gene showed that A:I:3 had the normal sequence expected for the blood-group M form of GPA (24).

Expression of the dRTA mutant proteins in Xenopus oocytes. The Xenopus oocyte does not express endogenous band 3 and this system has been well characterized for the heterologous expression of band 3 and measurement of band 3 functional activity $(28,30,38)$. We constructed the R589H, R589C and $\mathrm{S} 613 \mathrm{~F}$ mutations in both intact erythroid AE1 and the $\mathrm{NH}_{2}$-terminally truncated kidney isoform of AE1 (KAE1). Band 3-specific anion transport induced in the oocytes was estimated measuring the difference in radioactive chloride uptake in the presence and absence of 4,4'-dinitro-2,2'-stilbene disulfonate (DNDS). This expression system allows measurement of the transport activity of the pure mutant proteins, whereas both mutant and normal proteins are present in dRTA red cells. It also allows measurement of the transport activity for chloride anions, which are more physiologically relevant than sulfate as a transport substrate in the kidney. This is of particular importance because of the differences in the mechanism of transport of the two anions by AE1, and the very different results obtained for the transport of sulfate and iodide by the red cells of family D, who are heterozygous for the S613F mutation.

The uptake of chloride by the mutant AE1 proteins is shown in Fig. 6, $A$ and $B$. Although AE1(R589H) showed transport activity reduced to $40 \%$ of wild-type AE1, the R589C and 
a)

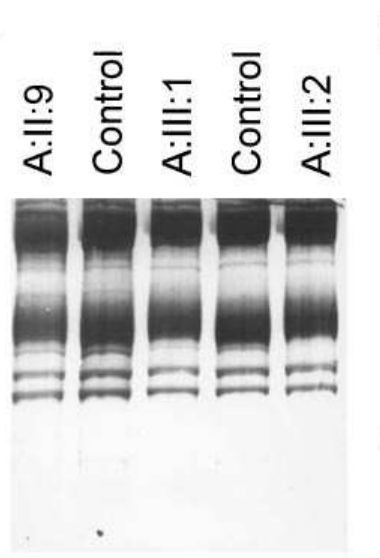

b)
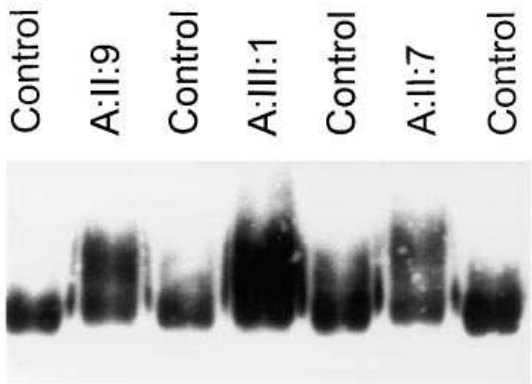

c)

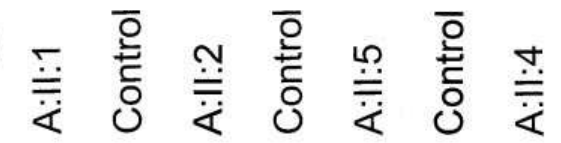

f)

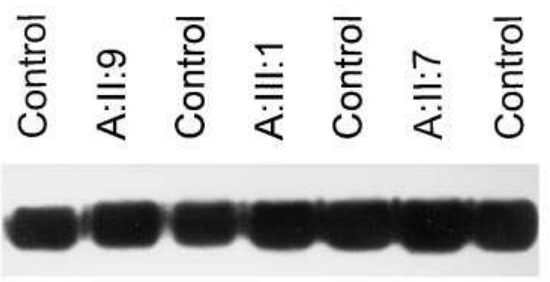

g)

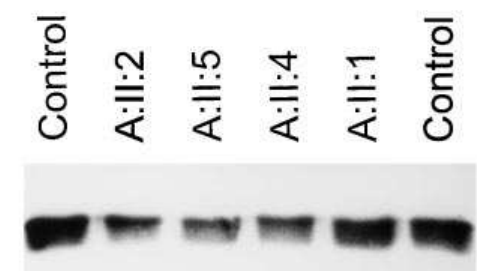

h)

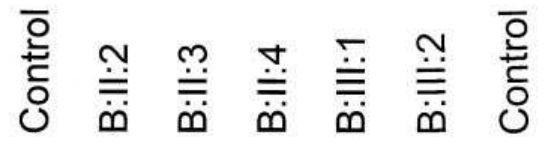

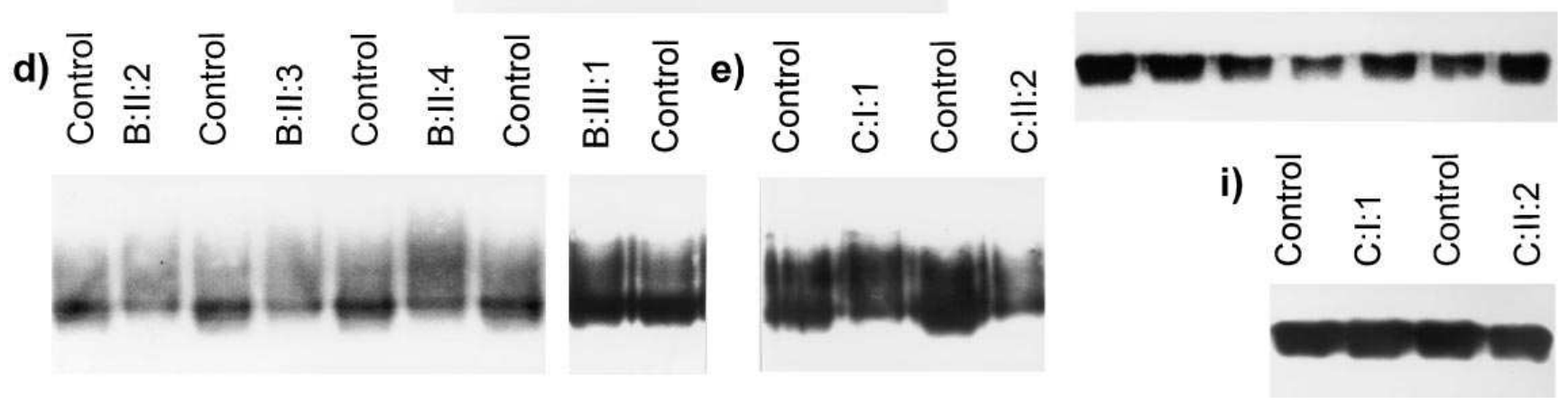

Figure 5. SDS-PAGE of membranes and band 3 from the families A, B, and C. (a) SDS-PAGE of red cell membranes from family A and normal controls. Membranes were prepared and separated on SDS gels containing $10 \%$ acrylamide and stained with Coomassie blue. (b-e) Immunoblots of membranes from chymotrypsin-treated red cells from families A, B, and C and normal control red cells. Immunoblots of SDS gels containing $8 \%$ acrylamide using anti-band 3 monoclonal antibody (BRIC 155) to detect the glycosylated COOH-terminal $35-\mathrm{kD}$ chymotrypsin fragment of band 3. $(f-i)$ Immunoblots of membranes from PNGase F and chymotrypsin-treated red cells from families A, B, and C and normal control red cells. Immunoblots of SDS-PAGE gels containing $8 \%$ acrylamide using anti-band 3 monoclonal antibody (BRIC 155) to detect the deglycosylated $\mathrm{COOH}$-terminal $35-\mathrm{kD}$ chymotrypsin fragment of band 3.

S613F variants had chloride transport activity similar to the wild-type protein. The kidney (KAE1) isoforms of the mutant proteins also showed chloride transport activity. The chloride transport activity of the KAE1(R589H) and R589C variants did not show a statistically significant difference from the wildtype KAE1. The results with KAE1(S613F) suggest it may have slightly reduced chloride transport activity compared with wild-type KAE1. These experiments clearly demonstrate that both the erythroid and kidney isoforms of all the variant proteins associated with dRTA retain substantial chloride transport activity, although in the case of the AE1(R589H) variant this is reduced compared with the wild-type protein. The anion transport activity of all the variant AE1 proteins was also enhanced by glycophorin A (GPA), as is the case for the wildtype protein (Fig. $6 \mathrm{~A}$ ). GPA also enhanced the expression of the anion transport activity of both wild-type KAE1 and the KAE1 variants (Fig. 6 B).

We also measured the band 3-specific chloride transport activity induced in oocytes on co-expression of equal amounts of normal and some of the variant protein cRNAs. The results for the AE1 isoforms of the $\mathrm{R} 589 \mathrm{H}$ and $\mathrm{R} 589 \mathrm{C}$ proteins and the KAE1 isoform of R589H (Fig. 6 C) show that the chloride transport activity resulting from co-expression of the wild type and these variant proteins did not differ significantly from that expected from the sum of the activity of the wild-type and variant proteins expressed separately.

\section{Discussion}

Mutations in the AE1 gene in families with autosomal dominant $d R T A$. We demonstrated the association between autosomal dominant dRTA and alterations in the $A E 1$ gene in the four families shown in Fig. 1 by linkage analysis and DNA sequence analysis. Linkage analysis on families A, B, and D using the microsatellite marker D17S759 provided strong support for the location of the dRTA gene in the region of chromosome 17 close to the $A E 1$ gene (and would be convincing even in the absence of a candidate gene). SSCP and DNA sequence studies of exons of the $A E 1$ gene showed that the affected individuals in families $\mathrm{A}$ and $\mathrm{B}$ were heterozygous for the mutation 
A

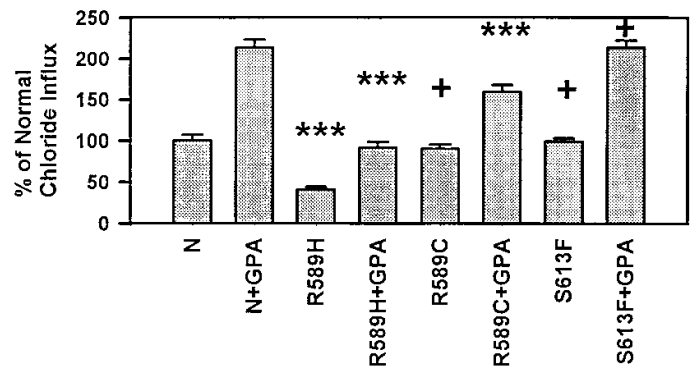

B

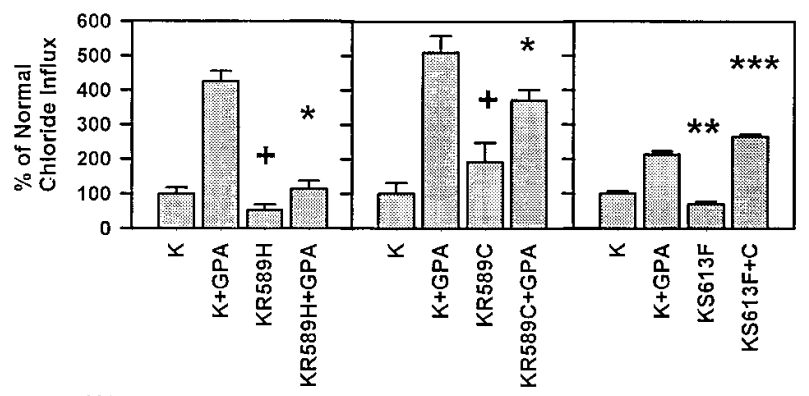

C

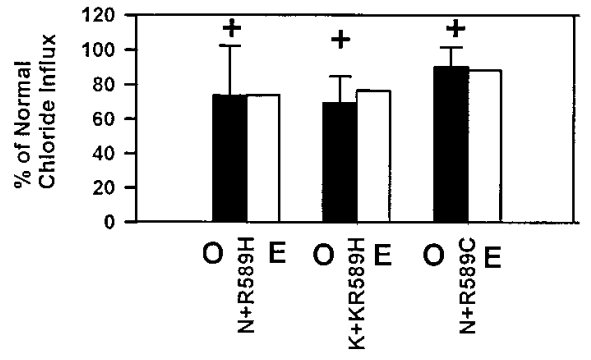

Figure 6. Chloride influx into Xenopus oocytes after expression of normal and kidney isoforms of variant AE1s. Xenopus oocytes were injected with in vitro transcribed cRNAs indicated in the Figure and the band 3-specific transport induced was estimated by measuring the DNDS-sensitive chloride influx as described in Methods. The results are expressed as the percentage of the chloride influx obtained using oocytes injected with the same amount of the appropriate normal AE1 control. The error bars represent the standard errors of the mean. The symbols above the bars show the statistical significance of the difference between the results obtained from the mutant and normal proteins as assessed by unpaired 2-tailed Student's $t$ tests. ${ }^{+} P>$ $0.05 ; * P<0.05$ and $>0.01 ; * * * P<0.001$. In the experiments where the constructs were coinjected with GPA cRNA, the appropriate normal AE1 coinjected with GPA cRNA was used as the basis for the comparison. ( $A$ ) Chloride influx induced in oocytes by expression of erythroid isoforms of variant AE1 constructs (R589H, R589C and S613F) compared with normal erythrocyte AE1 $(N)$. Experiments in which GPA was also coinjected are indicated by +GPA. $1 \mathrm{ng}$ of each AE1 cRNA was injected per oocyte, and when GPA was coexpressed 1 ng GPA cRNA was also injected per oocyte. (B) Chloride influx induced in oocytes by expression of kidney isoforms (KAE1) of variant AE1 constructs (KR589H, KR589C) compared with normal kidney KAE1 $(K)$. Experiments in which GPA was also coinjected are indicated by + GPA. 1 ng of each KAE1 cRNA was injected per oocyte, and when GPA was co-expressed 1 ng GPA cRNA was also injected per oocyte. $(C)$ Chloride influx (relative to the appropriate normal erythroid or kidney AE1 control) induced in oocytes by co-expression of variant erythroid AE1 (R589H or R589C) or variant kidney KAE1 $(K R 589 H)$ with an equal amount of the corresponding normal erythroid $(N)$ or normal kidney $(K)$ AE1. $O$ represents the experimentally observed chloride influx, and $E$ is the expected chloride influx calculated from the average of the measured influxes obtained when an equal amount of each cRNA was expressed alone. cRNAs were each injected at a concentration of $0.5 \mathrm{ng} /$
$\mathrm{R} 589 \mathrm{H}$ in AE1, and the affected individuals in family D were heterozygous for the mutation S613F. The unaffected members of these families were all homozygous for the normal AE1 sequence and it is clear that in these families the presence of dRTA correlates with the AE1 mutation. The two affected members of family $\mathrm{C}$ studied were both heterozygous for the mutation R589C. Since samples from unaffected members of this family were not available for study, we cannot be certain that the disease is also associated with this AE1 mutation. However, it is very likely that this is the case, particularly in view of the fact that this arginine residue is the same as that altered in families A and B.

We also sequenced the DNA of members of families A, B, and $\mathrm{D}$ in the region of the promoter for kidney band 3 transcripts which is located in erythroid intron 3 of the $A E 1$ gene $(12,13)$, since mutations in this region might specifically reduce or abolish the expression of band 3 in the kidney without affecting expression in the red cell. Although some individuals were found to be heterozygous for a sequence change in erythroid intron 3 which has not been previously described, the presence of this mutation did not correlate with the presence of dRTA, suggesting it is an unrelated polymorphism. These results suggest the dRTA condition in these families does not result from reduced expression of $A E 1$ transcripts in the kidney.

Our failure to find a common haplotype for the marker in the two families (A and B) with identical R589H mutations does not support a founder effect, but certainly does not exclude a common origin for the mutation, especially since both families originated in the same part of the republic of Ireland. The genetic distance between $A E 1$ and the marker tested is not known with precision. Since the work was completed it has been possible to obtain a slightly better estimate of the genetic position of $A E 1$ from consideration of results published in the radiation hybrid transcript map (39). This placed the EST RA17959 (GenBank T91230), shown by sequence comparison to be $A E 1$, between the genetic markers D17S800 and D17S930, about 3 centimorgans (cM) apart on the Genethon map (40). Reference to the integrated map on the location database (http://cedar.genetics.soton.ac.uk/public_html) suggests that D17S579 lies within this interval, probably within $\sim 1 \mathrm{cM}$ of $A E 1$, but the map order is unknown. More detailed study of the region would be necessary to confirm or refute a founder effect for the identical mutation in these two families.

Changes in red cell anion transport associated with autosomal dominant $d R T A$. We examined the band 3-mediated anion exchange properties of the red cells of affected individuals in families with dRTA to help us determine the transport properties of the mutant proteins. This might illuminate how the disease was related to alterations in the band $3 \mathrm{HCO}_{3}{ }^{-} / \mathrm{Cl}^{-}$ exchanger in the kidney. The sulfate transport activity of the red cells of the affected family members consistently differed from that of unaffected family members and unrelated control samples, although the nature of the sulfate transport change depended on the family studied. The affected members of families $\mathrm{A}, \mathrm{B}$, and $\mathrm{C}$ all showed red cell sulfate transport reduced to $75-80 \%$ compared with the unaffected members and con-

oocyte so that a total of $1 \mathrm{ng}$ cRNA was injected into each oocyte. The symbols above the bars represent the results of unpaired twotailed Student's $t$ tests to test the significance of the difference between the observed and expected results. + indicates a $P>0.05$. 
trol red blood cells. An increased apparent $K_{\mathrm{m}}$ for sulfate was found for the affected members of families A and B, suggesting that the decreased transport results from a decreased affinity of the altered AE1 for sulfate.

The amino acid altered in these families $\left(\operatorname{Arg}_{589}\right)$ is located in the cytoplasmic loop between transmembrane segments 6 and 7 of band 3 (Fig. 7). This arginine is conserved in all the known vertebrate sequences of the $A E$ gene family ( $A E 1, A E 2$, and $A E 3)$, suggesting it is functionally important. $\operatorname{Arg}_{589}$ is located in a cluster of basic residues (Fig. 7), which may form part of the cytoplasmic anion binding site of band 3 (41). The immediately adjacent amino acid residue $\left(\operatorname{Lys}_{590}\right)$ has an unusually low $\mathrm{pK}$, probably because of the large number of basic residues surrounding it, and can be specifically labeled at neutral $\mathrm{pH}$ with phenyl isothiocyanate (41). The covalent modification of this lysine residue is accompanied by inhibition of anion transport, suggesting that it might have a role in the anion transport process (42). The R589H and R589C mutations may raise the $\mathrm{pK}$ of $\mathrm{Lys}_{590}$ by reducing the number of positive charges surrounding the lysine residue, and thus affect the transport mechanism. In addition, the mutation may change the binding affinity for sulfate and thus give rise to the increased apparent $K_{\mathrm{m}}$ for sulfate observed in the red cell transport studies.

In contrast, the $\mathrm{S} 613 \mathrm{~F}$ mutation in family $\mathrm{D}$ results in a very marked increase in red cell sulfate transport, resulting from a large decrease in the apparent $K_{\mathrm{m}}$ for sulfate. The mechanism by which this mutation increases the affinity of the protein for sulfate is not clear. One possibility is that the mutation, which is located near the center of membrane span 7 (Fig. 7) and results in the substitution of serine by a bulky phenylalanine residue, alters the orientation of membrane span 7 relative to span 6. This may distort the conformation of the cytoplasmic loop between spans 6 and 7 which contains the putative anion binding site (Fig. 7) so that the clustered basic residues bind sulfate more tightly than the wild-type protein. While the S613F mutation shows a dramatic change in sulfate transport, there was little change in the transport parameters for the monovalent anion iodide, suggesting that the binding site for

EXTRACELLULAR

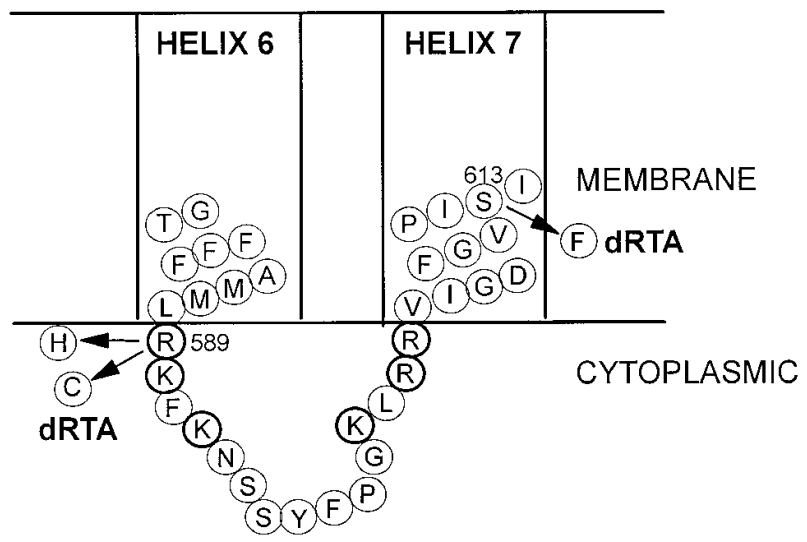

Figure 7. Amino acid sequence of band 3 around the dRTA mutations. Sequence of band 3 protein (57) around the dRTA mutations including the cytoplasmic loop between putative transmembrane regions 6 and 7. The basic residues clustered in this loop are shown in bold circles. monovalent anions is largely unaffected by the mutation. The $\mathrm{R} 589 \mathrm{H}$ and R589C mutants also change the cytoplasmic loop between membrane spans 6 and 7, and alterations in this region of the protein may have an important role in the mechanism of dRTA.

The erythroid and kidney isoforms of the expressed mutant AE1 proteins retain chloride transport activity. Although the changed kinetic constants for anion transport in the dRTA red cells suggest that the mutant proteins are expressed at the red cell surface, we could not directly measure the relative abundance of the variants compared with the normal protein in the red cells to estimate their transport activity. In addition, we measured the red cell transport activity for the slowly transported divalent anion, sulfate, because the very high monovalent anion transport activity of red cells makes it difficult to measure the transport of a physiologically relevant monovalent anion such as chloride. The different effects of the S613F mutation on sulfate and iodide transport made it desirable to measure the transport activity of the mutant proteins towards chloride. We therefore expressed the mutant proteins by themselves in Xenopus oocytes and measured their ability to induce band 3-specific chloride transport. The erythroid forms of the R589C and S613F mutant proteins showed normal chloride transport activity, while the activity of the R589H mutant was reduced. Constructs encoding the mutant kidney isoforms were also expressed and these gave chloride transport activities similar to the normal kidney isoform. Although there were some quantitative differences between the activities of the variant and normal proteins, it is important to note that both the erythroid and kidney isoforms of all the mutant proteins retained substantial chloride transport activity. The data also demonstrate that all the mutant proteins are expressed at the oocyte cell surface, as expected from the indirect evidence that the mutant proteins are expressed in the red cell membrane. Overall the results are consistent with the data on the transport activity of the mutant red cells, bearing in mind that the mutations may have different consequences on chloride and sulfate transport, as noted above for the iodide and sulfate transport activity of the S613F mutation. It is clear that the kidney isoforms of the mutant proteins can move to the cell surface of oocytes. It is very likely they can also move to the surface of renal $\alpha$-intercalated cells, although, unlike oocytes, the latter are polarized cells.

GPA enhances the expression of AE1-specific anion transport in Xenopus oocytes by facilitating the movement of AE1 to the cell surface, and it is suggested to have the same role in red blood cells (28). What role, if any, GPA plays in band 3 movement to the cell surface in the $\alpha$-intercalated cells of the kidney is unknown. Our experiments demonstrate that the chloride transport activity of all the variant AE1 proteins and the corresponding KAE1 isoforms was enhanced by GPA, suggesting that GPA also facilitates the movement of these proteins to the oocyte cell surface.

Since band 3 is present in the red cell membrane as an oligomer, and the dRTA patients are heterozygous for both the wild-type and variant proteins, it was possible that the wildtype and variant proteins could influence the activity of each other when they were present together in hetero-oligomers. We examined this question with the AE1 isoforms of the $\mathrm{R} 589 \mathrm{H}$ and R589C variants and the KAE1 isoform of the $\mathrm{R} 589 \mathrm{H}$ mutant. Co-expression of the normal and variant proteins yielded levels of chloride transport activity similar to that 
expected from the sum of the activities of the wild-type and variant proteins expressed separately, suggesting that the wildtype and variant proteins tested do not have a major effect on the activity of each other.

Altered red cell band $3 \mathrm{~N}$-glycan chain associated with the R589H and R589C dRTA mutations. The red cells of the affected members of families A-C showed an increase in the average size of the poly $\mathrm{N}$-acetyllactosamine-containing $\mathrm{N}$-glycan chain, which was not present in the unaffected family members (with the exception of A:II:7, see below). Abnormal elongation of the band 3 oligosaccharide chain due to the presence of additional $\mathrm{N}$-acetyllactosamine repeating units occurs when glycophorin $\mathrm{A}$ is absent from red cells (in $\mathrm{En}[\mathrm{a}-]$ and $\mathrm{M}^{\mathrm{k}}$ / $\mathrm{M}^{\mathrm{k}}$ red cells; 35-37). The enzymes responsible for the addition of the $\mathrm{N}$-acetyllactosamine units are located in the trans-most region of the Golgi system (43), and when GPA is absent band 3 probably remains longer in the Golgi complex during its movement to the plasma membrane (37). However, the red cells of families A, B, and C all contain normal GPA. The altered structure of the band $3 \mathrm{~N}$-glycan chain in the affected members of these families also very likely reflects a change in the processing of the $\mathrm{N}$-glycan chain and the biosynthetic pathway of band 3 as a consequence of the mutation of $\operatorname{Arg}_{589}$.

Unlike the other five unaffected individuals in families A and B, A:II:7 showed an altered N-glycan chain similar to that found in the dRTA samples in these families. A:II:7 has normal AE1 sequence and normal red cell anion transport as well as normal GPA and GPB. This change also reflects altered processing of the band $3 \mathrm{~N}$-glycan during band 3 biosynthesis in the erythroid cells of A:II:7 but its cause is unknown. It appears to be restricted to the branch of family A containing A:II:7 and may originate from her deceased father.

Autosomal dominant familial dRTA does not result simply from a change in $\mathrm{AE} 1 \mathrm{HCO}_{3}{ }^{-} / \mathrm{Cl}^{-}$anion exchange activity. We were originally prompted to carry out this study because of the possibility that there was an association between dRTA and hereditary ovalocytosis. This was suggested from the report of a Filipino family with both syndromes by Baehner et al., (44) and because one of us had seen three unrelated patients in Malaysia with both dRTA and ovalocytosis (Wrong, O., unpublished observations). The best characterized form of hereditary ovalocytosis (Southeast Asian ovalocytosis, SAO) results from the heterozygous presence of an abnormal band 3 (band $3 \mathrm{SAO}$ ) that has a deletion of residues 400-408, and gives rise to abnormally rigid red cells (6). Band $3 \mathrm{SAO}$ is misfolded in the membrane and can no longer transport anions, so that the red cells of SAO individuals have only about half the normal anion transport activity (25). It is clear that the families affected with dRTA studied here have mutations in band 3 which differ from band 3 SAO. Indeed, an individual with SAO (confirmed to be heterozygous for band 3 SAO; ref. 45) showed a normal ability to acidify urine and thus no evidence of dRTA (Bruce, L.J., P.S. Low, M.J.A. Tanner, R. Unwin, and $\mathrm{O}$. Wrong, unpublished observations).

Both the erythroid and kidney isoforms of the expressed dRTA variant band 3 proteins show levels of chloride transport activity similar to that of normal band 3 . This suggests that the transport activity of band 3 in the kidney intercalated cells of the dRTA patients is probably unchanged. The least active variant, $\mathrm{R} 589 \mathrm{H}$, has activity reduced to about half of the normal protein. If it is assumed that the dRTA individuals express equal amounts of normal and variant proteins, chloride transport would only be reduced by $\sim 25 \%$ in these cells, even in this case. It is difficult to see how the relatively small reduction in anion transport activity in these individuals heterozygous for the dRTA mutation should itself give rise to the dominant effect and result in the dramatic loss in acid-secreting capacity in the renal tubular cells. As indicated above, SAO individuals, who are heterozygous for a transport-inactive form of band 3 and show $\sim 40 \%$ of normal red cell anion transport (25), are not known to have impaired urinary acidification. Similarly, many mutations in band 3 are known which lead to hereditary spherocytosis, because the mutant band 3 is not incorporated into the red cell membrane (46). The red cells of these patients, who are heterozygous for the mutations, contain significantly decreased amounts of band 3 and show about half normal red cell sulfate transport (47), but these individuals have not been reported to show any defect in urinary acidification. In these cases reduction of band 3 transport activity to half normal or less does not result in dRTA. However, the complete absence of band 3 appears to result in defective renal acid secretion in cattle $(48,49)$, although it has not been reported whether a similar situation occurs in band 3-deficient mice (50).

We conclude that the disease in the IRTA families we have studied is not related simply to the anion transport activity of the mutant proteins. At present we can only speculate on the mechanism leading to the disease and its autosomal dominant inheritance in these families. The dominant effects of the mutations on acid secretion might be explained if the mutant protein formed a membrane ion shunt that dissipated the ionic gradients necessary for the net movement of acid across the renal tubular cell, and there are several possible ways by which this might occur. For example, if the mutant protein was mistargeted to the apical membrane, rather than the basolateral membrane where the normal protein resides, bicarbonate efflux into the tubular lumen by the mutant protein could neutralize the protons pumped by the apical $\mathrm{H}^{+}$-ATPase, so that there is no net transfer of hydrogen ions. Retargeting of AE1 from the basolateral to the apical membrane is suggested to occur during the conversion of acid-secreting $\alpha$-intercalated cells to bicarbonate-secreting $\beta$-intercalated cells (51). Equally, since the wild-type and mutant band 3 are likely to form heteroligomers, the presence of the mutant protein might also alter the normal basolateral targeting of the wild-type protein. Alternatively, the dRTA mutations could change the obligatory exchange transport activity of band 3 to a membrane channel or leak. Channel activity, as distinct from exchange transport activity, has been observed with trout AE1 (52). All these possibilities require further investigation.

The underlying mechanisms responsible for dRTA are likely to be different in different forms of the disease (3). The commonest form of dRTA is the one associated with multiple systemic autoimmune diseases and hypergammaglobulinemia, which has a slightly different phenotype from familial dRTA in that the condition is confined to post-pubertal women, and hypokalemia is more frequent and more severe (15). Renal biopsy of three of these patients, all with Sjögren's syndrome, has shown that their distal nephron intercalated cells do not stain for $\mathrm{H}^{+}$-ATPase. The same cells from two of the patients also did not stain for band 3 (53-55). We have no renal biopsy data from the present study as the dRTA patients would not agree to this procedure.

A large number of band 3 mutations are known which give 
rise to many red cell phenotypes $(46,56)$, some of which are important in clinical hematology. None of these are known to be associated with altered renal function. The new group of band 3 point mutations described in this paper alter kidney function but have no known hematological consequences. Further study of the properties of this class of band 3 mutations is likely to shed light on novel aspects of the molecular and cellular biology of band 3 and its role in acid secretion in the kidney.

\section{Acknowledgments}

This work was supported by grants from the National Kidney Research Fund (D.L. Cope and G.K. Jones), and the Wellcome Trust (L.J. Bruce and A.E. Schofield). G.K. Jones was partly supported by a Medical Research Council Research Studentship.

We are grateful to Zoe Patterson for technical assistance with DNA sequencing, D.J. Anstee for anti-GPA antibodies, R. Beckmann for the KAE1 cDNA, G. Rebello for help with computing and I.A. Hughes, M.A. Mansell, and R.G. Wolfson for access to their patients.

\section{References}

1. Morris, R.C., and H.E. Ives. 1996. Inherited disorders of the renal tubule. In The Kidney (5 ${ }^{\text {th }}$ ed.), B.M. Brenner, editor. W.B. Saunders, Philadelphia, PA. 1764-1827.

2. Kurtzman, N.A. 1990. Disorders of distal acidification. Kidney Int. 38: $720-727$.

3. O. Wrong, R. Unwin, E. Cohen, M. Tanner, and R. Thakker. 1996. Unravelling the molecular mechanisms of kidney stones. Lancet. 348:1561-1565.

4. Kopito, R.R. 1990. Molecular biology of the anion exchanger gene family. Int. Rev. Cytol. 123:177-199.

5. Alper, S.L. 1991. The band 3-related anion exchanger (AE) gene family. Ann. Rev. Physiol. 53:549-564.

6. Tanner, M.J.A. 1993. Molecular and cellular biology of the erythrocyte anion exchanger (AE1). Semin. Hematol. 30:34-57.

7. Wagner, S., R. Vogel, R. Lietzke, R. Koob, and D. Drenckhahn. 1987. Immunochemical characterisation of a band 3-like anion exchanger in collecting duct of human kidney. Am. J. Physiol. 253:213-221.

8. Alper, S.L., J. Natale, S. Gluck, H.F. Lodish, and D. Brown. 1989. Subtypes of intercalated cells in rat kidney collecting duct defined by antibodies against erythroid band 3 and renal vacuolar $\mathrm{H}^{+}$-ATPase. Proc. Natl. Acad. Sci. USA. 86:5429-5433.

9. Schuster, V.L., G. Fejes-Toth, A. Naray-Fejes-Toth, and S. Gluck. 1991. Co-localisation of $\mathrm{H}^{+}$-ATPase and band 3 anion exchanger in rabbit collecting duct intercalated cells. Am. J. Physiol. 260:F506-F517.

10. Brosius, F.C., S.L. Alper, A.M. Garcia, and H.F. Lodish. 1989. The major kidney band 3 gene product predicts an amino-terminal truncated band 3 polypeptide. J. Biol. Chem. 264:7784-7787.

11. Kudrycki, K.E., and G.E. Schull. 1989. Primary structure of the rat kidney band 3 anion exchange protein deduced from a cDNA. J. Biol. Chem. 264: 8185-8192.

12. Kollerton-Jons, A., S. Wagner, S. Hubner, H. Appelhans, and D. Drenckhahn. 1993. Anion exchanger 1 in human kidney and oncocytoma differs from erythroid AE1 in its $\mathrm{NH}_{2}$ terminus. Am. J. Physiol. 265:F813-F821.

13. Schofield, A.E., P.G. Martin, D. Spillett, and M.J.A. Tanner. 1994. The structure of the human red blood cell anion exchanger (EPB3, AE1, band 3) gene. Blood. 84:2000-2012.

14. Wainwright, S.D., M.J.A. Tanner, G.E.M. Martin, J.E. Yendle, and C. Holmes. 1989. Monoclonal antibodies to the membrane domain of the human erythrocyte anion transport protein. Biochem. J. 258:211-220.

15. Wrong, O.M., T.G. Feest, and A.G. Maciver. 1993. Immune-related potassium-losing interstitial nephritis: a comparison with distal renal tubular acidosis. Q.J. Med. 86:513-534.

16. Richards, P., and O.M. Wrong. 1972. Dominant inheritance in a family with familial renal tubular acidosis. Lancet. ii:998-999.

17. Wrong, O., and H.E.F. Davies. 1959. The excretion of acid in renal disease. Q.J. Med. 28:259-314

18. Buckalew, V.M., D.K. McCurdy, G.D. Ludwig, L.B. Chaykin, and J.R. Elkington. 1968. Incomplete renal tubular acidosis. Physiologic studies in three patients with a defect in lowering urine pH. Am. J. Med. 45:322-342.

19. Feest, T.G., S. Proctor, R. Brown, and O.M. Wrong. 1978. Nephrocalcinosis: another cause of renal erythrocytosis. Br. Med. J. ii:605-606.

20. Agroyannis, B., D. Koutsikos, H. Tzanatos-Exarchou, and H. Yatzidis. 1992. Erythrocytosis in type 1 renal tubular acidosis with nephrocalcinosis.
Nephrol. Dial. Transplant. 7:365

21. Fain, P.R. 1992. Third international workshop on human chromosome17 mapping. Cytogenet. Cell Genet. 60:178-186.

22. Sambrook, J., E.J. Fritsch, and T. Maniatis. 1989. Molecular cloning: A Laboratory Manual. 2nd Edition. Cold Spring Harbor Laboratory Press, Cold Spring Harbor, NY.

23. Orita, M., H. Iwahana, H. Kanazawa, K. Hayashi, and T. Swyika. 1989. Detection of polymorphisms of human DNA by gel electrophoresis as singlestrand conformation polymorphisms. Proc. Natl. Acad. Sci. USA. 86:2766-2770.

24. Kudo, S., and M. Fukuda. 1989. Structural organization of glycophorin A and B genes: Glycophorin B gene evolved by homologous recombination at Alu repeat sequences. Proc. Natl. Acad. Sci. USA. 86:4619-4623.

25. Schofield, A.E., D.M. Reardon, and M.J.A. Tanner. 1992. Defective anion transport activity of the abnormal band 3 in hereditary ovalocytic red cells Nature (Lond.). 355:836-838

26. Spring, F.A., L.J. Bruce, D.J. Anstee, and M.J.A. Tanner. 1992. A red cell band 3 variant with altered stilbene disulfonate binding is associated with the Diego $\left(\mathrm{Di}^{\mathrm{a}}\right)$ blood group antigen. Biochem. J. 288:713-716.

27. Laemmli, U.K. 1970. Cleavage of structural proteins during the assembly of the head of bacteriophage T4. Nature (Lond.). 227: 680-681.

28. Groves, J.D., and M.J.A. Tanner 1992. Glycophorin A facilitates the expression of human band 3-mediated anion transport in Xenopus oocytes. J. Biol. Chem. 267: 22163-22170.

29. Padgett, K.A., and J.A. Sorge. 1995. Creating seamless junctions independent of restriction sites in PCR cloning. Gene. 168:31-35.

30. Garcia, A.M., and H.F. Lodish. 1989. Lysine 539 of human band 3 is not essential for anion transport or inhibition by stilbene disulfonates. J. Biol. Chem. 264:19607-19613.

31. Groves, J.D., and M.J.A. Tanner. 1994. The effects of glycophorin A on the expression of the human red cell anion transporter (band 3) in Xenopus oocytes. J. Memb. Biol. 140:81-88.

32. Passow, H. 1986. Molecular aspects of band 3 protein-mediated anion transport across the red blood cell membrane. Rev. Physiol. Biochem. Pharmacol. 103:61-223.

33. Mueller, T.J., and M. Morrison. 1977. Detection of a variant of protein 3 , the major transmembrane protein of the human erythrocyte. J. Biol. Chem. 252:6573-6578.

34. Fukuda, M., A. Dell, J.E. Oates, and M.N. Fukuda. 1984. Structure of branched lactosaminoglycan, the carbohydrate moiety of band 3 isolated from adult human erythrocytes. J. Biol. Chem. 259:8260-8279.

35. Tanner, M.J.A., R.E. Jenkins, D.J. Anstee, and J.R. Clamp. 1976. Abnormal carbohydrate composition of the major membrane-penetrating protein of En(a-) human erythrocytes. Biochem. J. 155:701-703.

36. Gahmberg, C., G. Myllyla, J. Liekola, A. Pirkola, and S. Nordling. 1976. Absence of the major sialoglycoprotein in the membrane of human En(a-) erythrocytes and increased glycosylation of band 3. J. Biol. Chem. 251:61086116.

37. Bruce, L.J., J.D. Groves, Y. Okubo, B. Thilaganathan, and M.J.A. Tanner. 1994. Altered band 3 structure and function in glycophorin A and glycophorin B-deficient $\left(\mathrm{M}^{\mathrm{k}} / \mathrm{M}^{\mathrm{k}}\right)$ red blood cells. Blood. 84:3590-3598.

38. Bartel, D., S. Lepke, G. Layh-Schmitt, B. Legrum, and H. Passow. 1989. Anion transport in oocytes of Xenopus laevis induced by expression of mouse erythroid band 3 -encoding cRNA and of a cRNA derivative obtained by sitedirected mutagenesis at the stilbene-disulphonate binding site. EMBO J. 8: 3601-3609.

39. Schuler, G.D., M.S. Boguski, E.A. Stewart, L.D. Stein, G. Gyapay, K. Rice, R.E. White, P. Rodriguez-Tome, A. Aggarwal, E. Bajorek, et al. 1996. A gene map of the human genome. Science (Wash. DC). 274:540-545.

40. Dib, C., S. Faure, C. Fizames, D. Samson, N. Drouot, A. Vignal, P. Millasseau, S. Marc, E. Seboun, M. Lathrop, G. Gyapay, J. Morrisette, and J. Weissenbach. 1996. A comprehensive genetic map of the human genome based on 5,264 microsatellites. Nature (Lond.). 380:152-154

41. Brock, C.J., M.J.A. Tanner, and C. Kempf. 1983. The human erythrocyte anion transport protein: partial amino acid sequence, conformation and a possible molecular mechanism for anion exchange. Biochem. J. 213: 577-586.

42. Kempf, C., C.J. Brock, H. Sigrist, M.J.A. Tanner, and P. Zahler. 1981. Interaction of phenylisothiocyanate with human erythrocyte band 3 protein. Biochim. Biophys. Acta. 641:88-98.

43. Wang, W.C., N. Li, D. Aoki, M.N. Fukudo, and M. Fukuda. 1991. The poly-N-acetyllactosamines attached to lysosomal membrane glycoproteins are increased by the prolonged association with the Golgi complex. J. Biol. Chem. 266:23185-23190.

44. Baehner, R.L., G.S. Gilchrist, and E.J. Anderson. 1968. Hereditary elliptocytosis and primary renal tubular acidosis in a single family. Am. J. Dis. Child. 115:414-419.

45. Morayama, R., H. Ideguchi, C.R. Lombardo, H.M. van Dort, and P.S. Low. 1992. Structural and functional characterisation of band 3 from Southeast Asian ovalocytes. J. Biol. Chem. 287:25792-25797.

46. Lux, S.E., and J. Palek. 1995. Disorders of the red cell membrane. In Blood: Principles and Practice. R.I. Handin, S.E. Lux, and T.P. Stossel, editors J.B. Lippincott, Philadelphia, PA. 1701-1808.

47. Jarolim, P., H.L. Rubin, V. Brabec, L. Chrobak, A.S. Zolotarer, S.L. 
Alper, C. Brugnara, H. Wichterle, and J. Palek. 1995. Mutations of conserved arginines in the membrane domain of erythroid band 3 lead to a decrease in membrane associated band 3 , and to the phenotype of hereditary spherocytosis. Blood. 85:634-640.

48. Inaba, M., A. Yawata, I. Koshino, K. Sato, M. Takeuichi, Y. Takakuwa, S. Manno, Y. Yawata, A. Kanzaki, J. Sakai, A. Ban, K. Ono, and Y. Maede. 1996. Defective anion transport and marked spherocytosis with membrane instability caused by hereditary total deficiency of red cell band 3 in cattle due to a nonsense mutation. J. Clin. Invest. 97:1804-1817.

49. Tanner, M.J.A. 1996. The acid test for band 3. Nature (Lond.). 382:209-210. 50. Peters, L.L., R.A. Shivdasani, S.C. Liu, M. Hanspal, K.M. John, J.M. Gonzalez, C. Brugnara, B. Gwynn, N. Mohandas, S.L. Alper, S.H. Orkin, and S.E. Lux. 1996. Anion exchanger 1 (band 3) is required to prevent erythrocyte membrane surface loss but not to form the membrane skeleton. Cell. 86:917-927.

51. Al-Awqati, Q. 1996. Plasticity in epithelial polarity of renal intercalated cells: targeting of the H+-ATPase and band 3. Am. J. Physiol. 270:C1571C1580.

52. Fievet, B., N. Gabillat, F. Borgese, and R. Motais. 1995. Expression of band 3 anion exchanger induces chloride current and taurine transport: structure-function analysis. EMBO J. 14:5158-5165.

53. Cohen, E.P., B. Bastani, M.R. Cohen, S. Kolner, P.H. Hemken, and S.L. Gluck. 1992. Absence of $\mathrm{H}^{+}$-ATPase in cortical collecting tubules of a patient with Sjögren's syndrome and distal renal tubular acidosis. J. Am. Soc. Nephrol. 3:264-271

54. De Franco, P., L. Haragsim, P. Schmitz, and B. Bastani. 1994. Absence of vacuolar $\mathrm{H}^{+}$-ATPase in intercalated cells of a patient with classic distal renal tubular acidosis (dRTA). J. Am. Soc. Nephrol. 5:367A.

55. Bastani, B., L. Haragsim, S. Gluck, and K.C. Siamopoulos. 1995. Lack of $\mathrm{H}^{+}$-ATPase in distal nephron causing hypokalaemic distal RTA in a patient with with Sjögren's syndrome. Nephrol. Dial. Transplant. 10:908-909.

56. Bruce, L.J., and M.J.A. Tanner. 1996. Structure-function relationships of band 3 variants. Cell. Mol. Biol. 42:953-973.

57. Tanner, M.J.A., P.G. Martin, and S. High. 1988. The complete amino acid sequence of the human erythrocyte membrane anion transport protein deduced from the cDNA. Biochem. J. 256:703-712. 